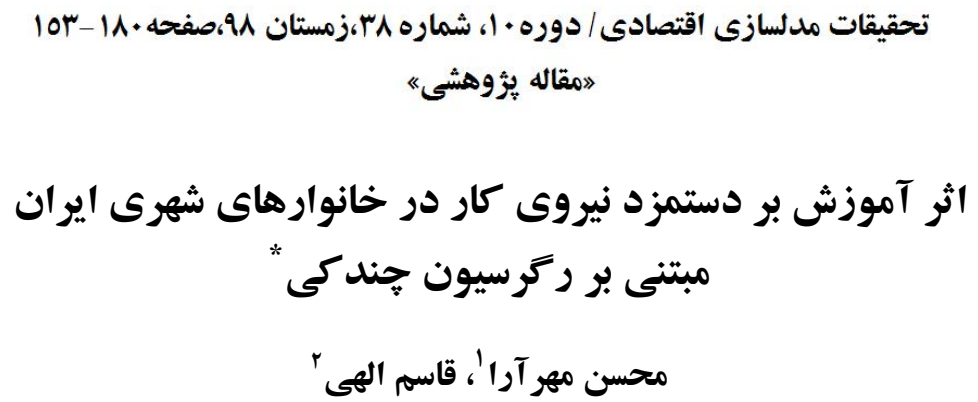


تحصيلات زنان اين شكاف را تاحدى به نفع زنان كاهش داده است. مطابق نتايج حاصله بازدهى تحصيلات در ايران به مراتب كمتر از بسيارى از ديخر كشورهاى جهان مىباشدان.

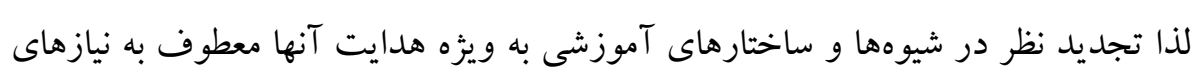

$$
\text { بازار كار و صرفه هاى اقتصادى ضرورى است. }
$$

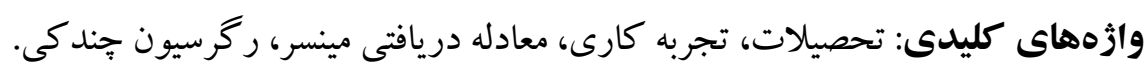
طبقلبندى J24,I21,C21:JEL 


\section{1. مقدمه}

در جامعه امروز درصد بالايى از هرم سنى جمعيت را جوانانى تشكيل مىدهند كه

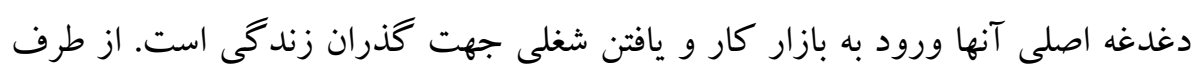

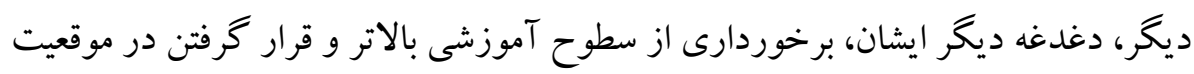

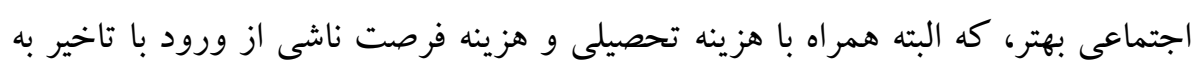

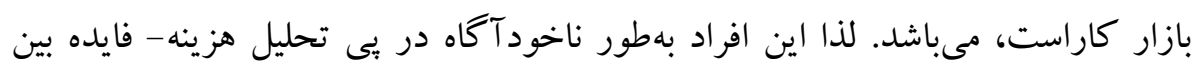
دستيابى به مقاطع تحصيلى بالاتر و ورود با تاخير به بازار كار هستند.

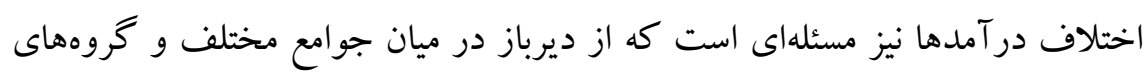

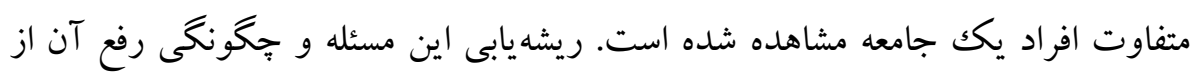

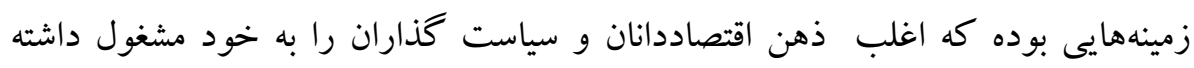
است. ييدايش علم اقتصاد آموزش، توجيه جديدى از وجود اختلاف درآمدها را براى

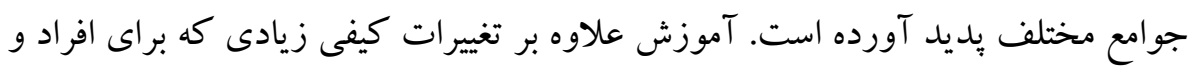

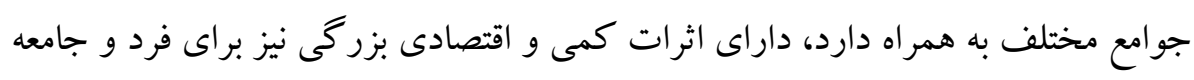
فر اهم مى آورد. امروزه توسعه اقتصادى پايدار، بلدون سرمايه كذارى بر روى سرمايه انسانى امكان بذّير

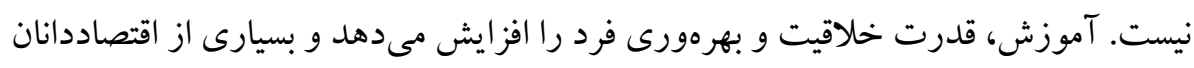

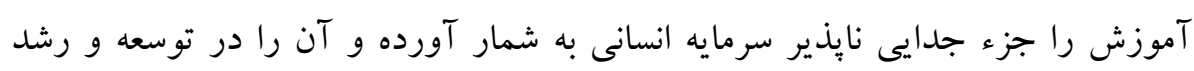

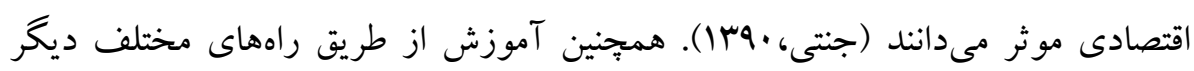
مانند تاثير بر سلامتى افراد مىتواند بر افزايش بهرهورى سرمايه انسانى موثر باشد. با بانس

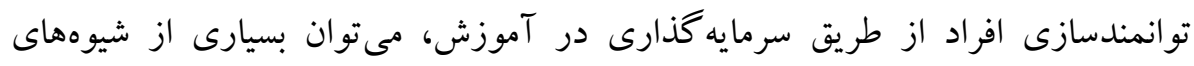

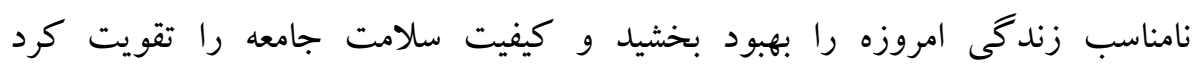


شوالتز' ( •199) مفهوم سرمايه انسانى را وارد ادبيات اقتصادى كرد كه به موجب آن

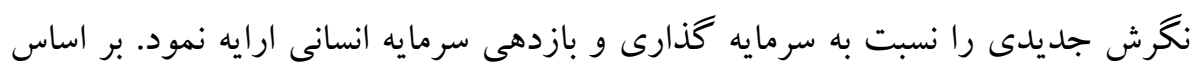
نظريه وى سرمايه انسانى يكك عامل توليد است كه ماند ساير نهادهها همجيجون سرمايه

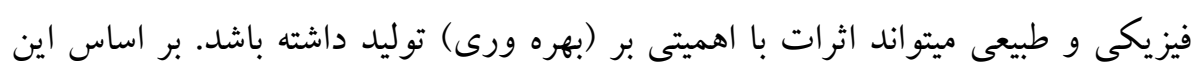

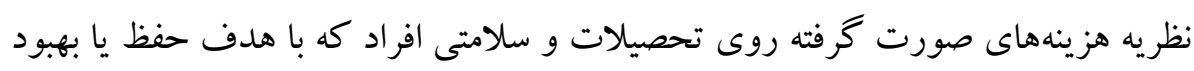
بهرهورى او انجام مى شود، ديخر مخارج مصرفى به حساب نمى آيند بلكه از ماهيت سرمايه كذارى برخوردارند. اصطلاح سرمايه انسانى براى دانش، مهارتها يا شايستخىهايى به كار رفته است كه

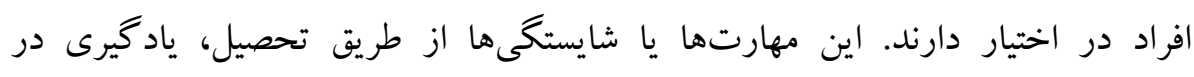

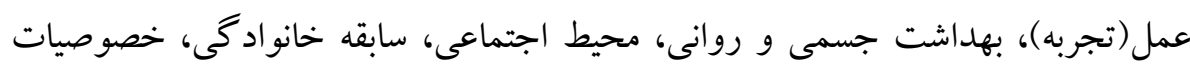

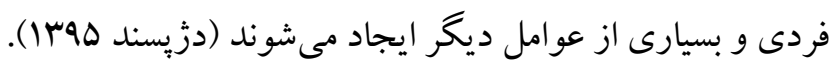

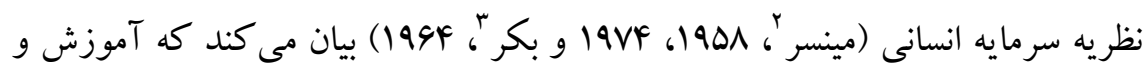

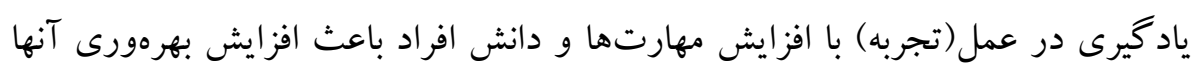
مىشود. اين افزايش در مهارتها و دانش موجب افزايش دستمزد دريافتى افراد مى كرددد.

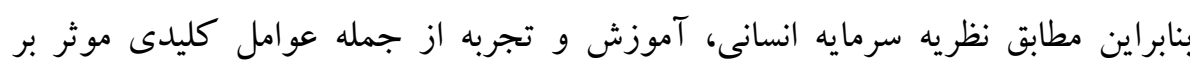

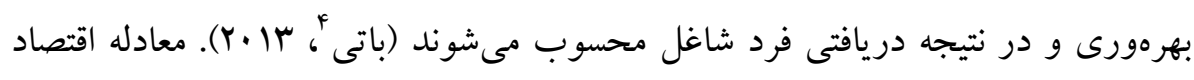

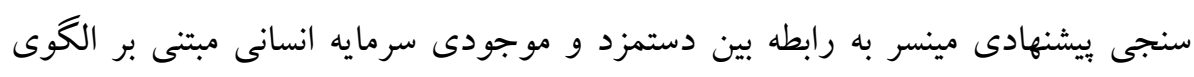

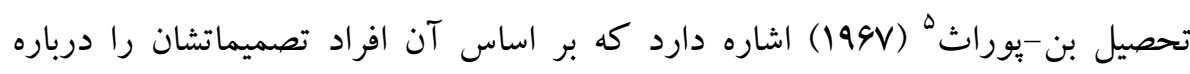

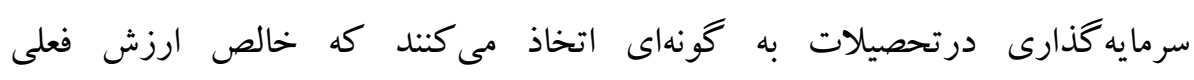
دريافتى هايشان حداكثر شود.

1. Schultz

1.Mincer

2.Becker

3. Bhatti

4. Ben-Porath 
ايده اصلى نظريه سرمايه انسانى اين است كه افراد به انتظار بازدهىهاى مادى و

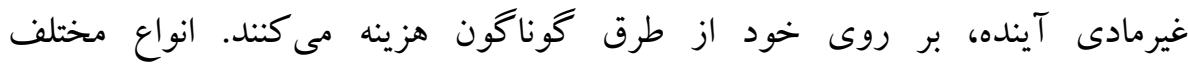

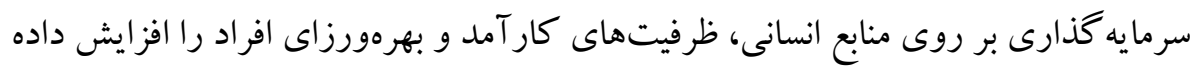

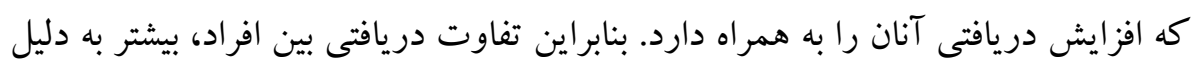

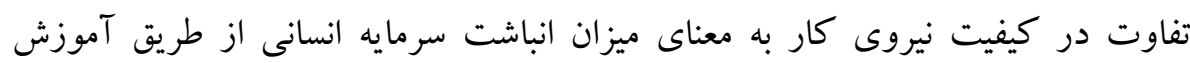
رسمى، آموزش ضمن كار و ياد گيرى به هنگام كار است.

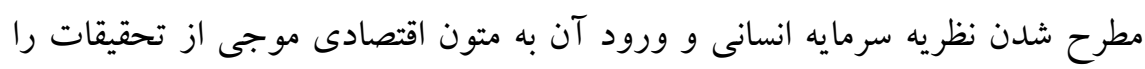
براى تخمين معادله مينسر به راه اندخت تا ميزان بازدهى آموزش رسمى (تحصيل) بر اساس ورد اس به

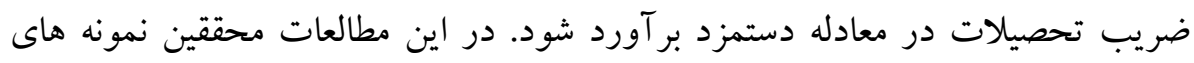

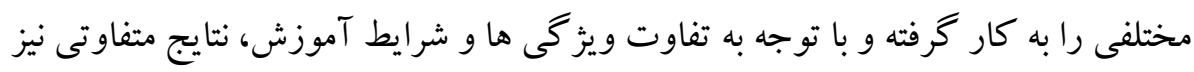

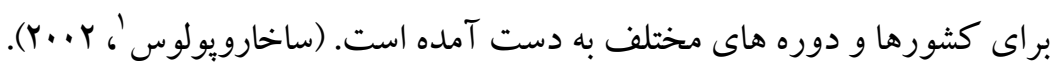
با توجه به اهميت آموزش و تاثير آن بر درآمد افراد، در مقاله حاضر به بررسى نرخ بازدهى آموزش و اثر تحصيلات و تجربه بر درآمد افراد، براى كشور ايران در سال هوها

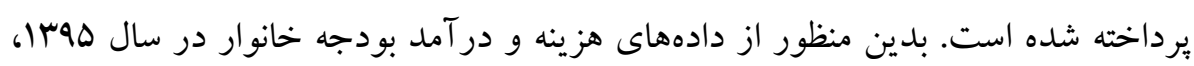

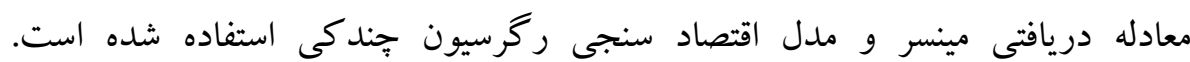

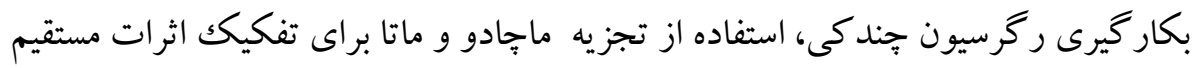
و غير مستقيم جنسيت بر دريافتىها (كه اولى به اثر تبعيض و دومى به اثر ويز گیى ها شهرت

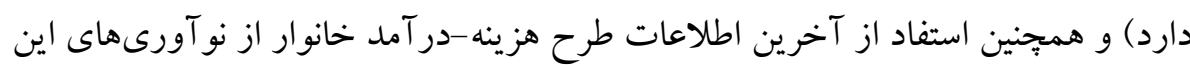

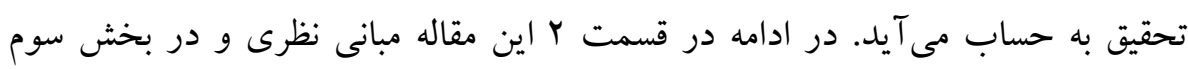
ادبيات تجربى تحقيق مرور مىشوند. در قسمت جهارم مدل اقتصاد سنجى تصريح شده و يس از تبيين متغيرها و دادهها، نتايج تحقيق ارايه و تحليل مى شوند. در قسمت ينجم مقاله، خلاصه مباحث مذكور ارايه و نتيجه گيرى مىشوند.

1. Psacharopoulos 
r. مبانى نظرى تحقيق

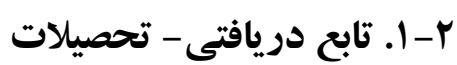

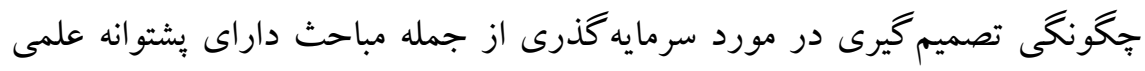

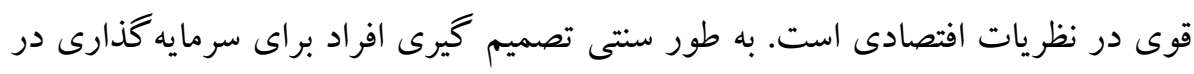
سرمايه انسانى از طريق تحصيلات و يادكيرى در عمل (تجربه)، همانند هر سرمايه گذارى ديخرى با تحليل هزينهها و منافع آن سرمايه گذارى انجام مىشود. تحليل هاى هزينه - فايده

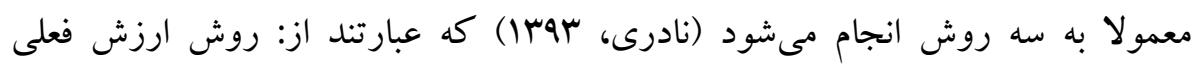

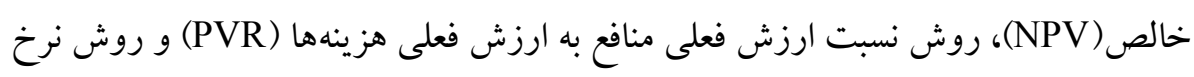
بازده داخلى (r).

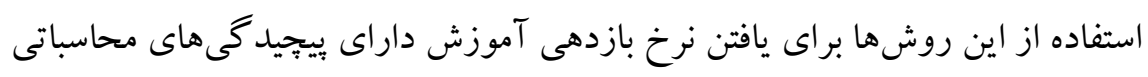

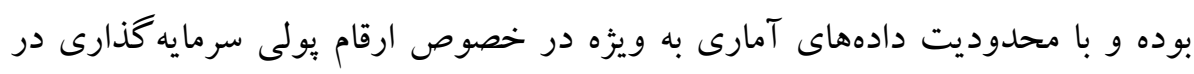

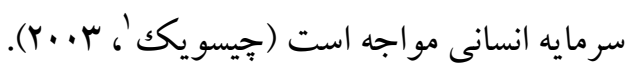

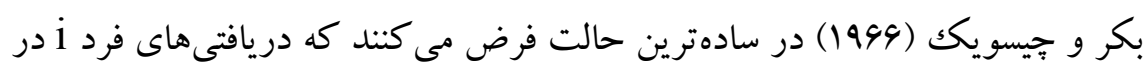
سال (E برابر است با دريافتىهاى اوليه قبل از سرمايه كذارى (E)

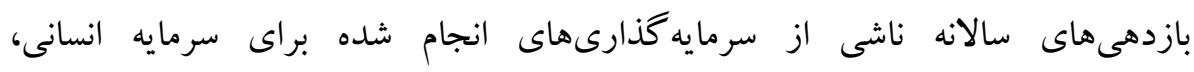

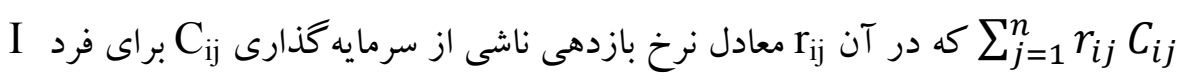

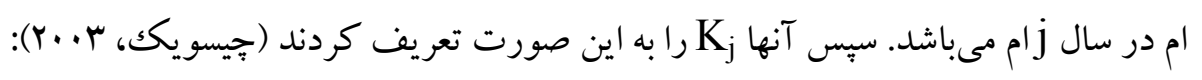
K ب بنابر اين مىتوان نشان داد كه:

$E_{i j}=E_{i 0}+\sum_{j=1}^{n} r_{i j} C_{i j}=E_{i 0}+\sum_{j=1}^{n} r_{i j} K_{i j} E_{i . j-1}$

كه با استفاده از اصل استقر ارياضى، رابطه فوق را مىتوان به صورت زير نوشت: 


$$
\begin{gathered}
E_{i j}=E_{i 0} \prod_{j=1}^{n}\left(1+r_{i j K_{i j}}\right) \\
\operatorname{LnE}_{i j}=\operatorname{Ln} E_{i 0}+\sum_{j=1}^{n} \operatorname{Ln}\left(1+r_{i j K_{i j}}\right)
\end{gathered}
$$

با استفاده از اين خاصيت كه اكر $\delta$ عدد كوجكى باشد آنغاه ، $\delta$ ( رابطه بالا را مىتوان به صورت زير نوشت:

$L n E_{i j} \cong L n E_{i 0}+\sum_{j=1}^{n} r_{i j} K_{i j}$

اين رابطه لكاريتم دريافتىها را بر حسب نرخ بازدهى ناشى از سرمايه گذارى در

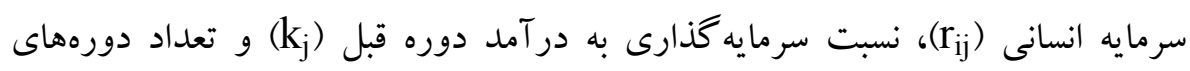

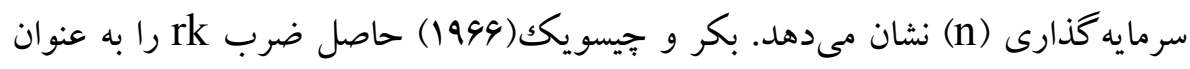

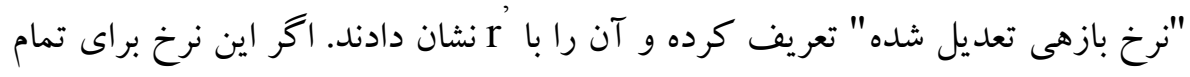

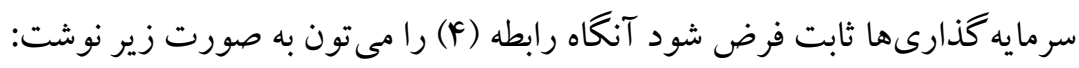
$L n E_{i j}=L n E_{0}+r_{i}^{\prime} n_{i}+U_{i}$

به گونهاى كه جمله اخلال Ui اثر ساير متغيرهاى حذف شده( مانند شانس، سلامت و...) بر روى دريافتى ها را اندازه گيرى مى كند. جيسويك (199VV) با ذكر اين نكته كه آنه

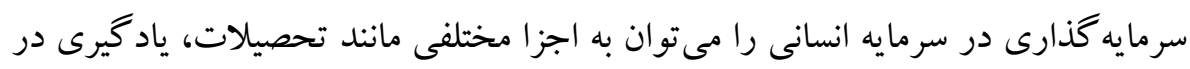

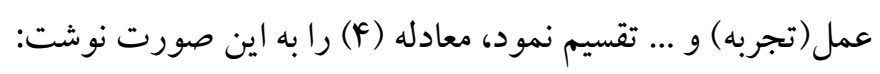




$$
\begin{gathered}
L n E_{i j}=\operatorname{Ln} E_{0}+\sum_{s=1}^{S i} r_{i . s}^{\prime}+\sum_{j=1}^{J i} r_{i . j}^{\prime} \\
+U_{i}
\end{gathered}
$$

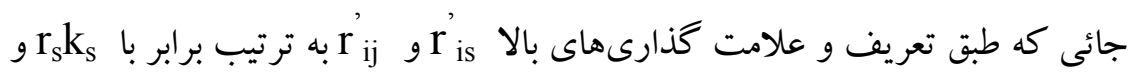

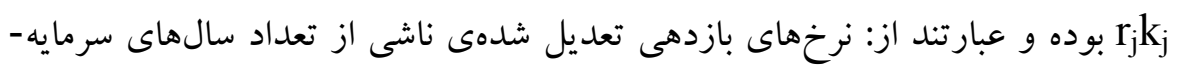

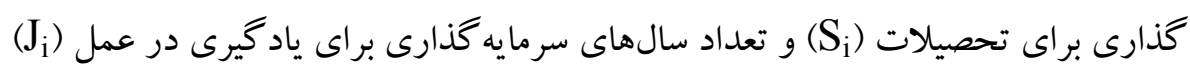

بكر و جيسويكك (1999) بيان مى كنند با وجود آنكه اطلاعات نسبتا دقيق و كامل در مورد تعداد سالهاى تحصيلات رسمى وجود دارد ولى در مورد يادگيرى در عمل

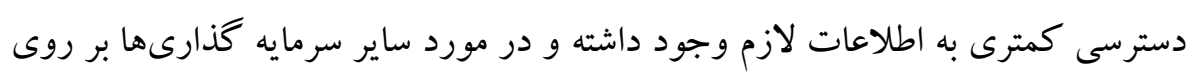

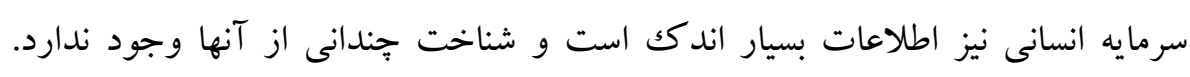
نويسند گان مذكور اشاره دارند كه متاسفانه تنها عملى كه در خنين شرايط مئى توان انجام

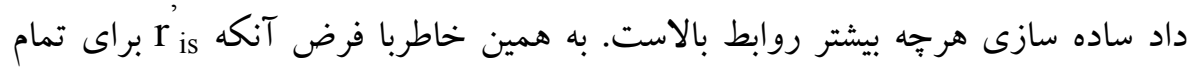

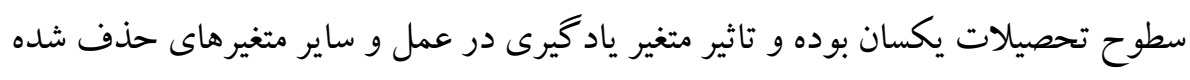

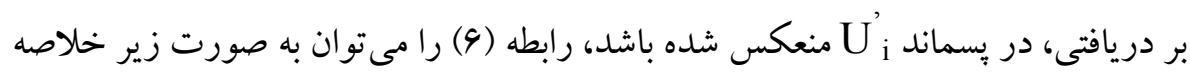
كرد: $L n E_{0}=L n E_{i 0}+r_{i}^{\prime} S_{i j}+U_{i}^{\prime}$

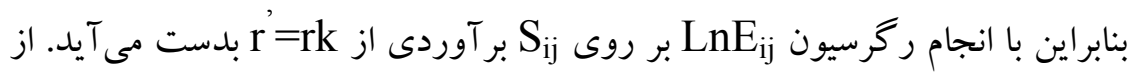
اين معادله ركرسيون مىتوان براى تخمين نرخ بازدهى تعديل شدهى ناشى از تحصيلات 
استفاده كرد و با فرض آنكه k=1 باشد، رگرسيون مذكور نرخ بازدهى تحصيلات رسمى را تخمين مىزند'.

\section{r-r. r. تابع در آمد كسب شده از محل سرمايه انسانى}

در سال l9VF مينسر در كتاب معروف خود با عنوان (تحصيلات، تجربه و دريافتىها)

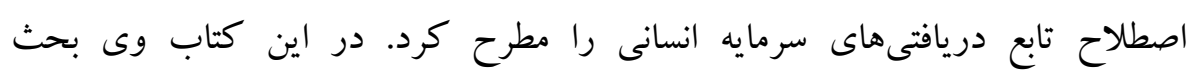

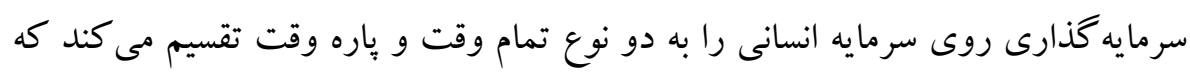

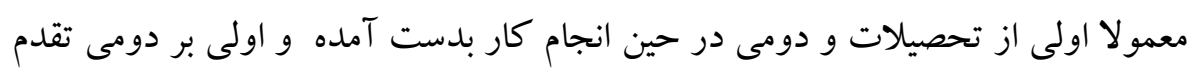

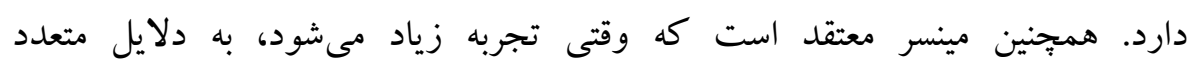

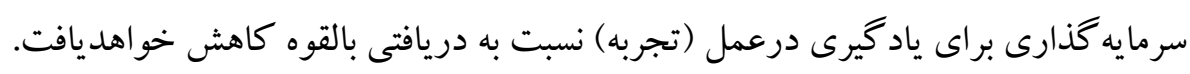

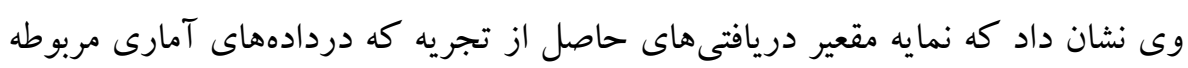

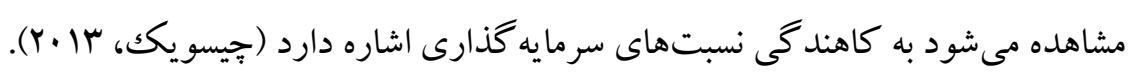

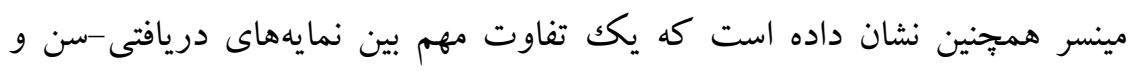

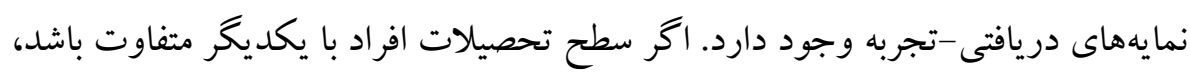
آنها در سنى كه سرمايه گذارى بعد از تحصيلات(يادكيرى در عمل) را شروع مى كنند نيز

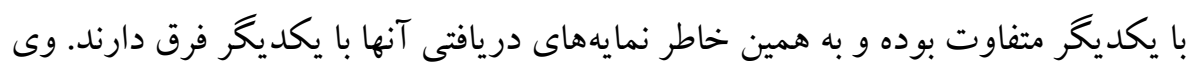

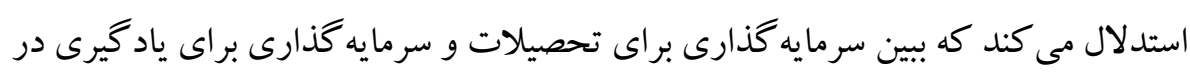

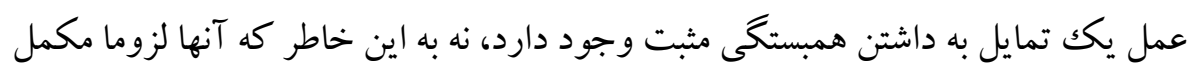

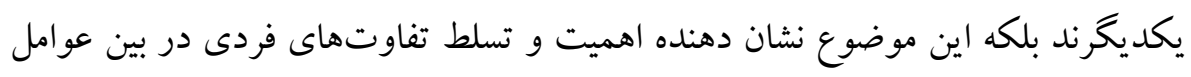

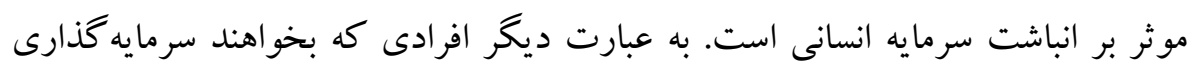

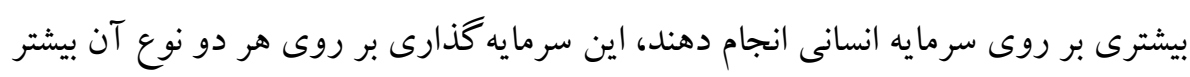

ا. در مطالعات تجربى مقدار k نزديك به عدد يكك بر آورد شده و با استناد به نتايج اين مطالعات براى ساده سازى معادله مذكور

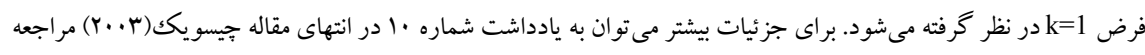


خواهد بود. در غياب اطلاعات مستقيم از تجربه كارى، مينسر "كسر كردن سن اتمام

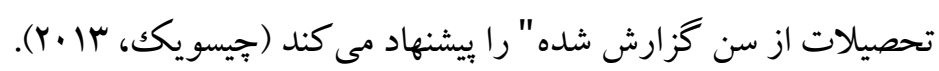
قبل از برداختن به نحوه استخراج معادله ركرسيون دريافتى سرمايه انسانى توسط مينسر بايد اين نكته را در نظر گرفت كه براى تصميم گيرى در مورد سرمايه گذارى بر روى سرى سرمايه

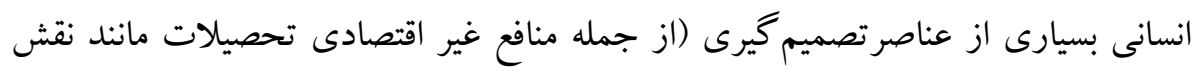

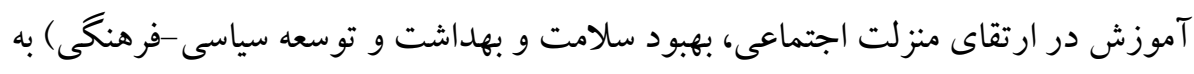

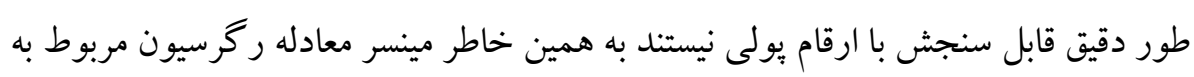

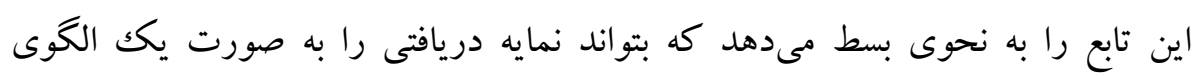

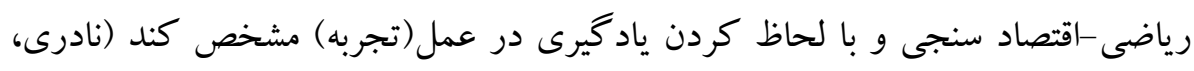
תוra)

مينسر به خاطر رديابى دادههاى آمارى و عمدتا از آنجا كه اطلاعات مربوط به تحصيلات و

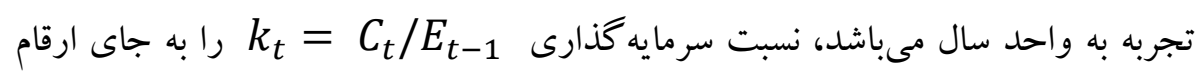

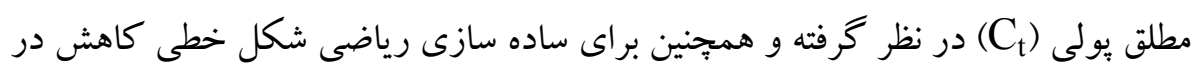

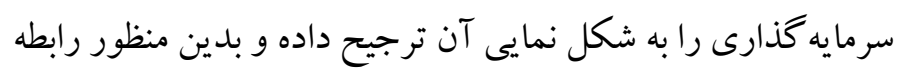
T Tام إ $k_{t}=k_{0}-\frac{k_{0}}{T^{*}} T_{t}$

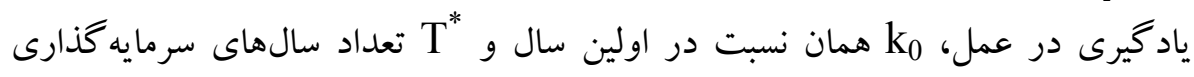
خالص مثبت هستند. اكر LnEt لكاريتم دريافتىها در سال t بوده و

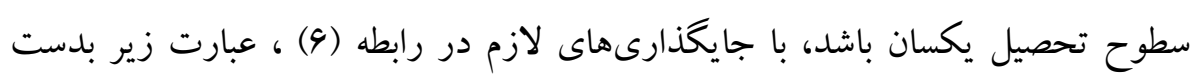

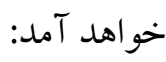

$$
L n E_{i t}=\operatorname{Ln} E_{i 0}+r_{s} k_{s} S_{i}+\left(r_{j} k_{0}\right) T_{i}-\left(\frac{r_{j} k_{0}}{2 T^{*}}\right) T_{i}^{2}
$$


كه در آن rij نرخ بازدهى ناشى از سرمايه گذارى براى ياد گيرى در عمل (تجربه) است. در

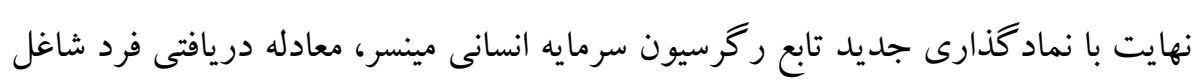
به صورت زير تصريح شده است:

$\operatorname{LnE}_{\mathrm{i}}=\beta_{0}+\beta_{1}$ edu $+\beta_{2} \exp +\beta_{3} \exp ^{2}+\mathrm{U}_{\mathrm{i}}$

كه در آن ei edu، exp، به ترتيب دريافتىها، تعداد سال هاى تحصيل و تعداد سال هاى تجربه كارى بالقوه بعد از تحصيل ( يعنى سن منهاى تعداد سال هاى تحصيل منهاى

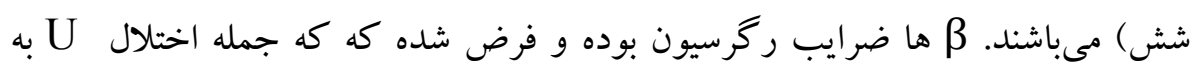

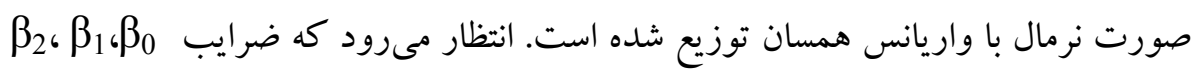

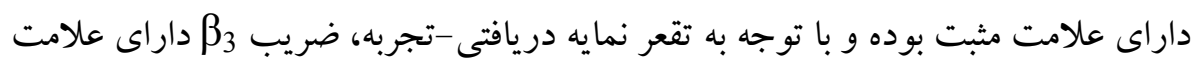

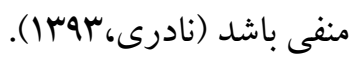
تابع دريافتى سرمايه انسانى داراى ويزگى هاى برجستهى زير است كه آن را جذاب

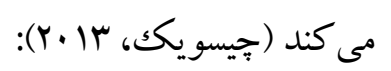
- فرم تابعى آن بر اساس رفتار بهينهازى سرمايه كذارى فرد در بازار كار بدست

- اين تابع هزينه يولى سرمايه كذارى در سرمايه انسانى را بر حسب سالهاى تحصيل و سالهاى تجربه كارى استفاده مى كند.

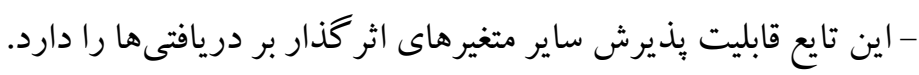

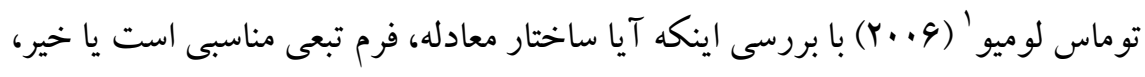

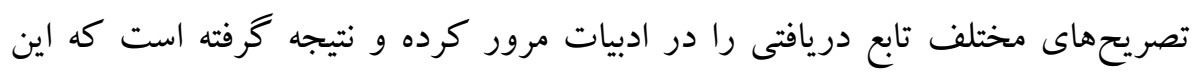

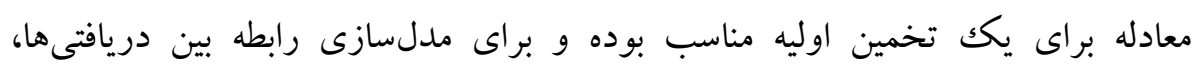
تحصيلات و تجريه يكك روش نسبتا دقيق است. 
r. ب. بيشينه تحقيق

افشارى (ITVV) در مقالهاى با عنوان (ابررسى اثر تحصيلات عالى و تجربه بر دريافتى

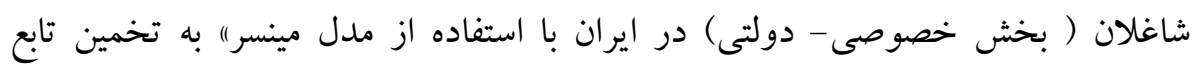
دريافتى مينسر با استفاده از روش حداقل مربعات معمولى و حداقل مربعات وزنى برداخته

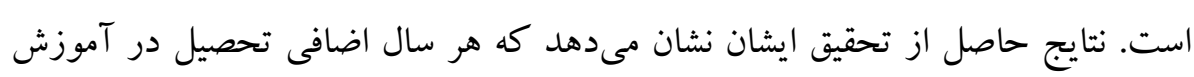

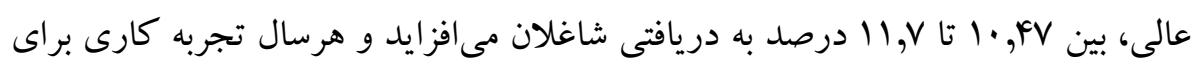
دانش آموختكان آموزش عالى نيز ه, ب درصد به دريافتىها اضافه مى كند. كسرائى(

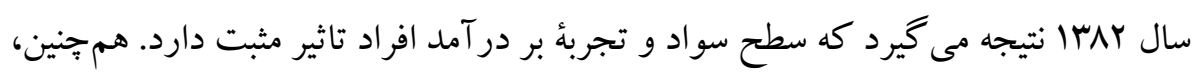
تبعيض جنسى در تفاوت درآمدى افراد وجود دارد. بهطورى كه با فرض ثبات ساير شر ايط در آمد حاصل از شغل مردان بهطور متوسط، لع VF درصد بيشتر از زنان است.

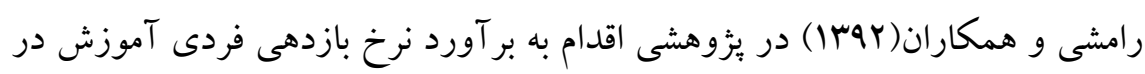
ايران بر حسب جنسيت دانش آموختگان شاغل و نوع آموزش، مبتنى بر تابع دريافتى مينسر

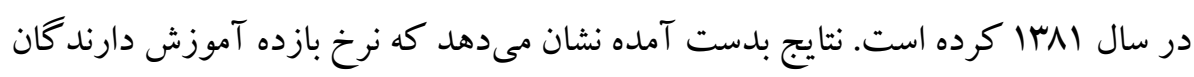
تحصيلات عالى، بيشتر از ساير افراد، براى شاغلان در بخش خصوصى بـ بيشتر از شاغلان در برد

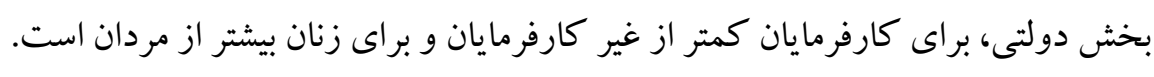

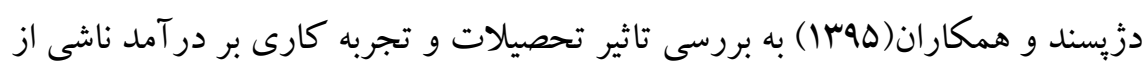

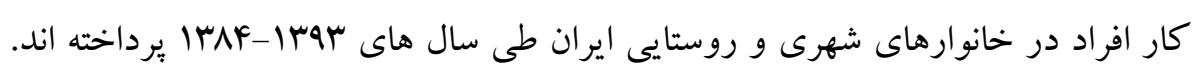

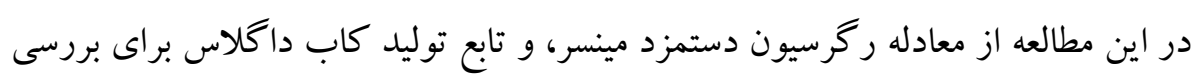

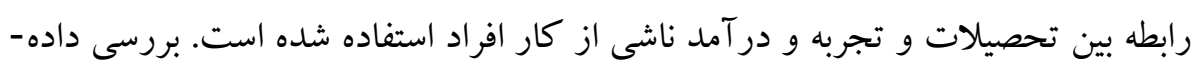

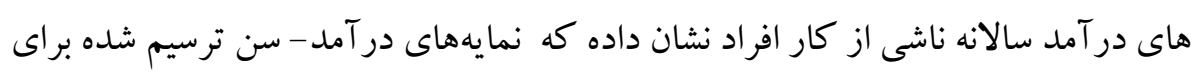

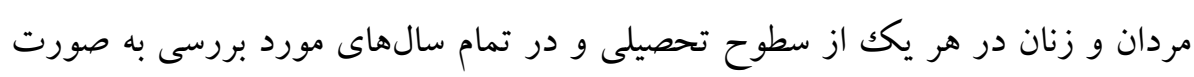

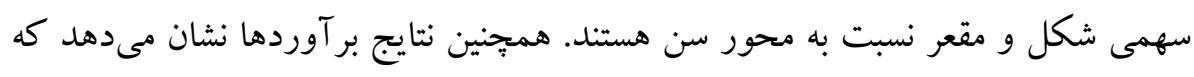
متغيرهاى تحصيلات و تجربه بر در آمد سالانه ناشى از كار تاثير مثبت دارند. 
مهلدوى و ييروزراهى(IrqV) نرخ بازده خصوصى تحصيلات تكميلى در ايران را با

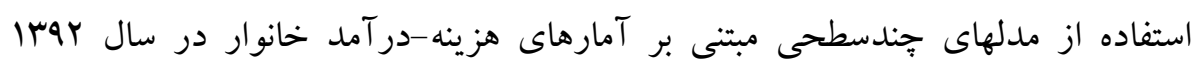
برآورد مى كند. مهمترين نتايج تحقيق نشان مىدهد كه تحصيلات تكميلى بر درآمد

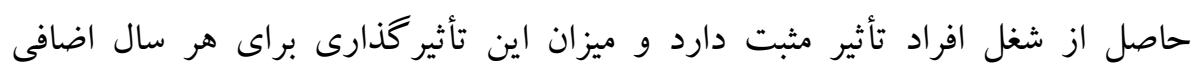
تحصيلات تكميلى حدود س/r/ درصد است. ميزان تأثير تجربه كارى بر دريافتىها نيز حدود r/9 درصد بر آورد شده است. تحسيل موكك و نكاتارامن' (1999) با برآورد تابع دريافتى مينسر براى اقدود اقتصاد ويتنام نشان

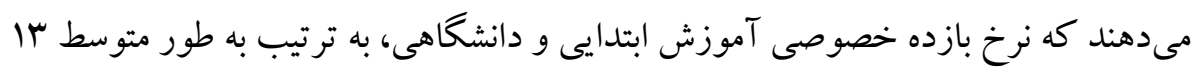

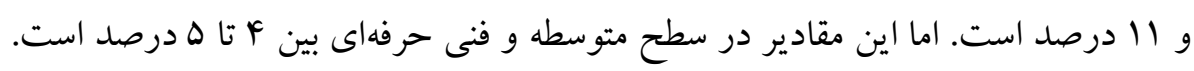
بازدهى تحصيلات بالاتر براى زنان (rادرصد)، بيش از مردان ( •ادرصد) است.

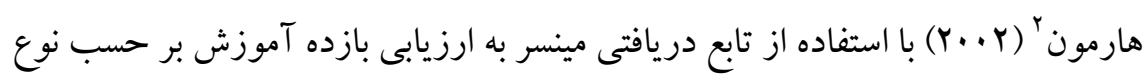

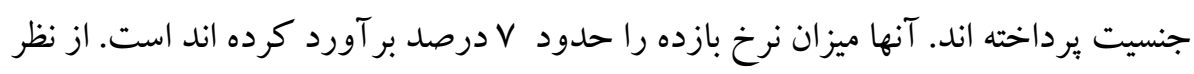

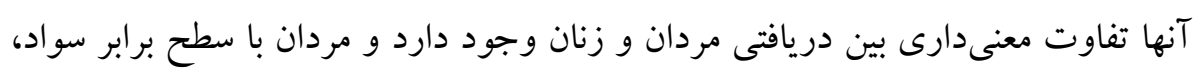

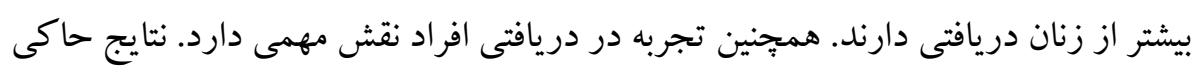
از آن است كه رابطه دريافتى فرد و متغير تجربه مقعر است.

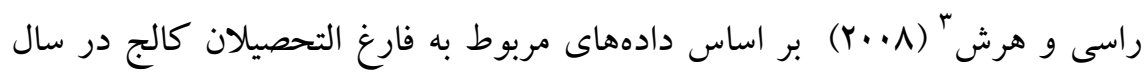

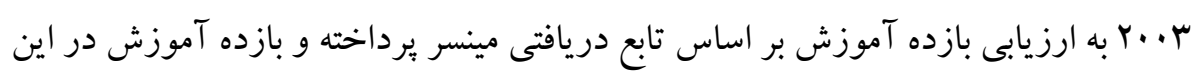

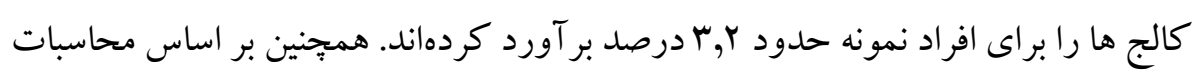
آنها نرخ بازده آموزش براى فارغ التحصيلان رشته هاى هنر، علوم انسانى و علوم اجتماعى بردي بسيار كمتر از فارغ التحصيلان رشتههاى فنى و مهندسى است و بازده فارغ التحصيلان

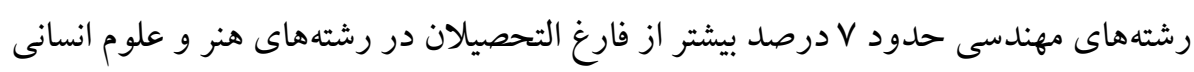


كوانوان' (Y (Y. أثر آموزش بر دريافتى نيروى كار رادر كشور اندونزى در بازه زمانى

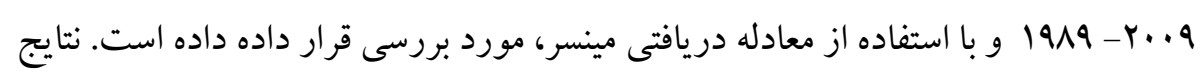
اين تحقيق نشان مىدهد كه اثر آموزش بر در آمد نيروى كار همواره مثبت بوده و در سطح

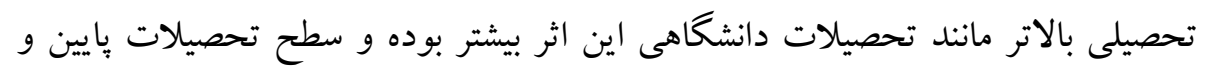

$$
\text { اوليه كمترين اثر مثبت را داشته است. }
$$

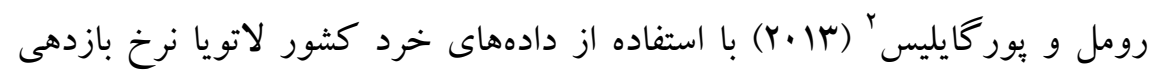

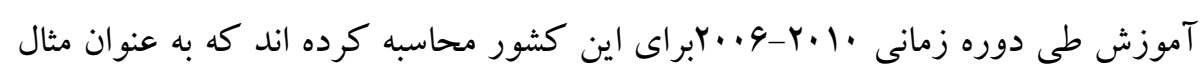

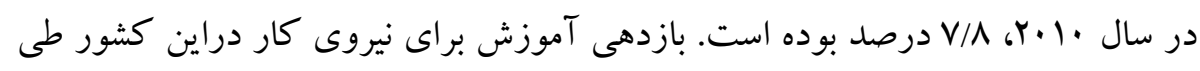

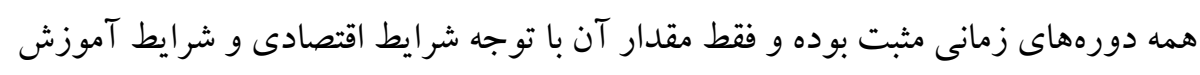
در سالهاى مختلف، متفاوت بوده است.

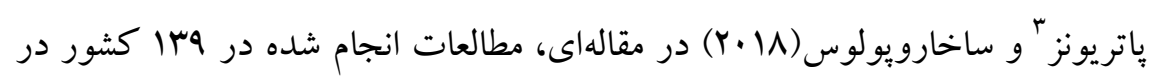

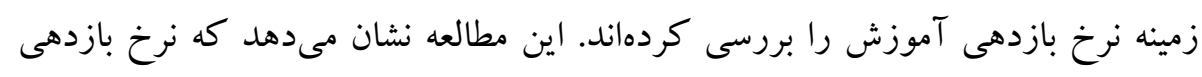

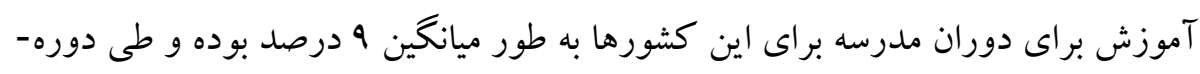

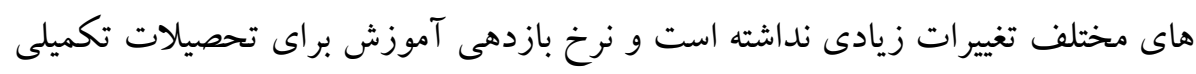

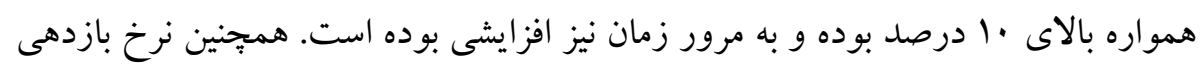

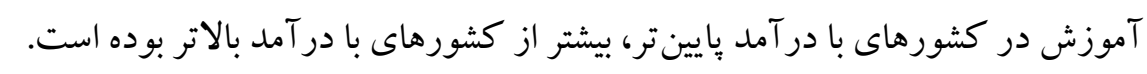

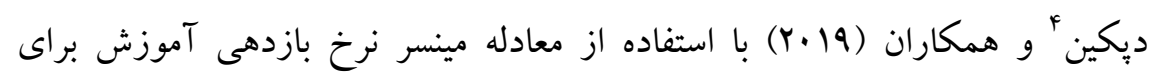

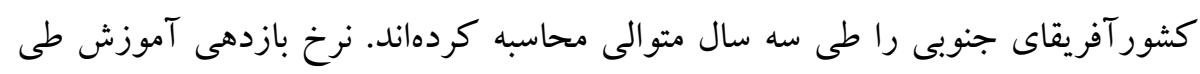

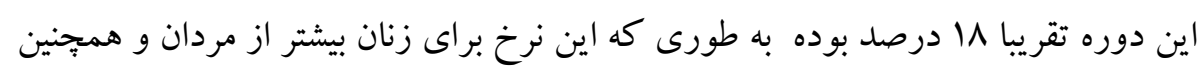
براى مناطق شهرى بيشتر از مناطق روستايى بوده است.

4. Guanawan

1.Romele \& Purgailis

2.Patrions

3.Depcken 
هوف استيونز' و همكاران (Y. Y. نرخ بازدهى آموزش فنى و حرفهاى را براى ايالت

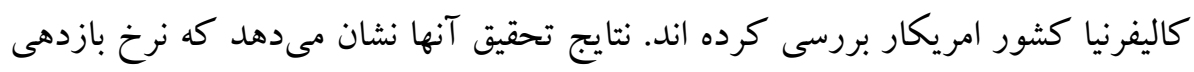

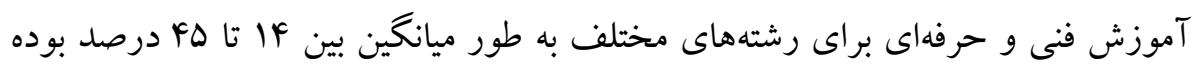

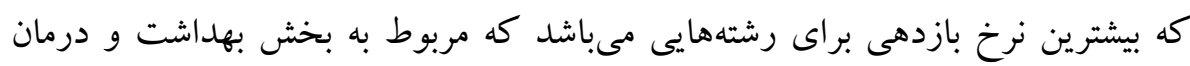

\section{ع. التو، دادهها و نتايج تجربى}

\section{ع-1. مدل رگرسيون جندكى}

در آمار و ادبيات اقتصادسنجى، ميانگين يكى از معيارهاى تمر كز است و مقدار آن به

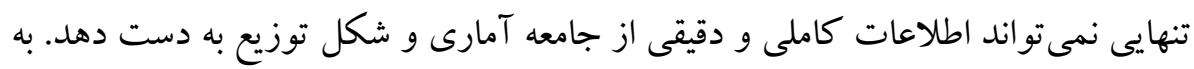

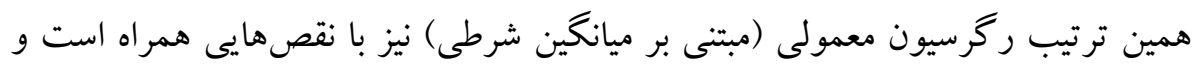

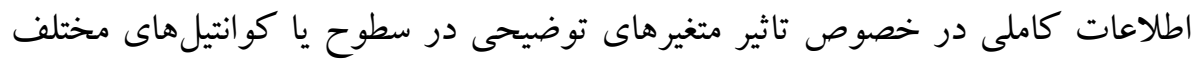

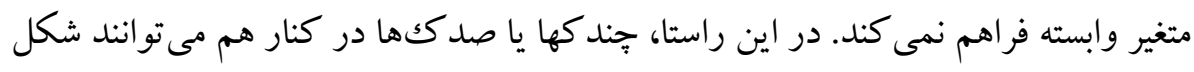
توزيع و روابط ميان متغيرها در صدككهاى مختلف را به صورت جامعترى به تصوير

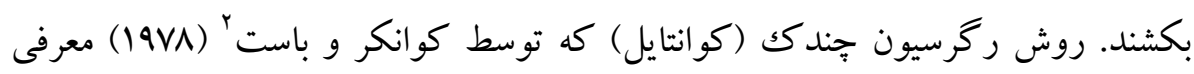
شد، برخلاف روش حداقل مربعات معمولى اثر نهايى متغيرهاى توضيحى بر متغير وابسته

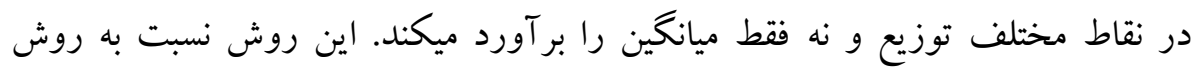
حداقل مربعات معمولى داراى مزايايى است، ازجمله ويز گیىهاى اين روش حساسيت كمتر

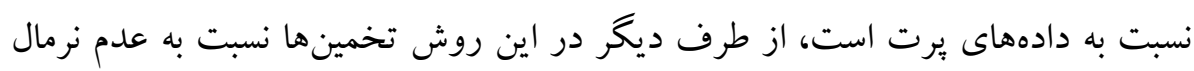

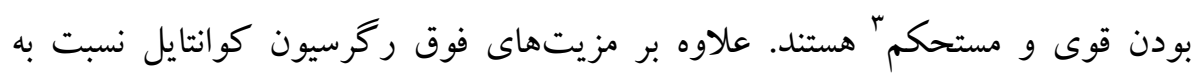


حداقل مربعات معمولى، در حضور ناهمسانى واريانس از استحكام نتايج بيشترى برخوردار

مدل اقتصادسنجى كوانتايل يا ركرسيون براى كو انتايل ح ام متغير وابسته بهعنوان تابع خطى از متغيرهاى توضيحدهنده بهصورت زير تصريح مىشود:

$y_{i}=x_{i}^{\prime} \beta_{\tau}+U_{\tau i}$, Quant $_{\tau}\left(y_{i} \mid x_{i}\right)=x_{i}^{\prime} \beta_{\tau}$

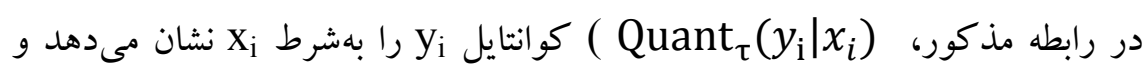
متضمن آن است كه Quant ${ }_{\tau}\left(U_{\tau i} \mid x_{i}\right)=0$. متغيرهاى توضيحى بر توزيع شرطى متغير وابسته بر اساس مينيمم كردن مجموع قدر مطلق

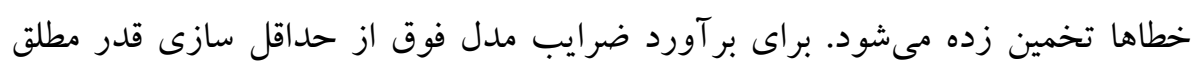

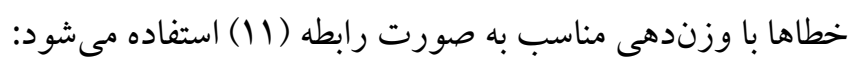

$$
\begin{aligned}
\min \beta_{\tau}=\min & \left\{\sum_{i: y_{i} \geq x_{i}^{\prime} \beta_{\tau}} \tau\left|y_{i}-x_{i}^{\prime} \beta_{\tau}\right|\right. \\
& \left.+\sum_{i: y_{i}<x_{i}^{\prime} \beta_{\tau}}(1-\tau)\left|y_{i}-x_{i}^{\prime} \beta_{\tau}\right|\right\}
\end{aligned}
$$

لازم به ذكر است كه انخيزه اصلى به كارگيرى رگرسيون جندكىها در اين بثزوهش

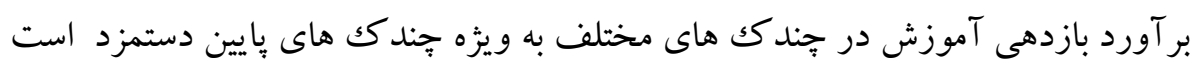

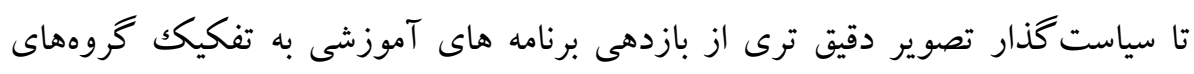
مختلف بهدست آورد. 


\section{ع-r. الكوى تحقيق و داده هاى آمارى}

در مطالعه حاضر از داده هاى خام درآمد و هزينه خانوارهاى شهرى ساده سال هوسا استفاده شده است. يرسشنامه بودجه خانوار از جهار بخش كلى تشكيل شده است. قسمت اول، خصوصيات اجتماعى اعضاى خانوار را شامل مى شود. قسمت دوم، محل سكونت و و

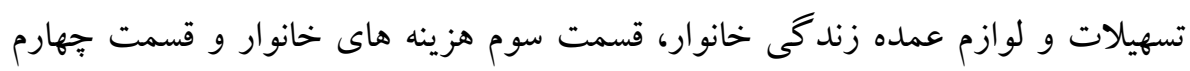

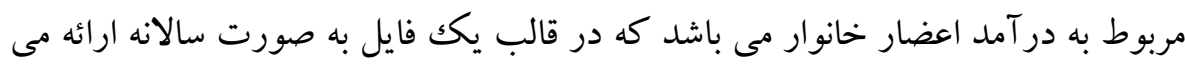
شود.

$$
\text { الكوى تحقيق بصورت زير تصريح مى شود: }
$$

$\operatorname{LnE}_{\mathrm{i}}=\beta_{0}+\beta_{1} \operatorname{edu}+\beta_{2} \exp +\beta_{3} \exp ^{2}$ $+\beta_{3}$ married $+\beta_{4}$ gender $+\mathrm{U}_{\mathrm{i}}$

$$
\text { در ادامه متغيرهاى تحقيق تبيين مى گردد. }
$$

تحصيلات(edu): در برسش نامه هزينه و درآمد خانوار، دو ستون به منظور شناسايى سطح سواد و تحصيلات افراد وجود دارد. يكك ستون وضع سواد و تحصيل و ديخرى با ندان استفاده از كدهاى تحصيل، مدركك تحصيلى فرد را مشخص مى كند. ستون دوم فقط براى افرادى بر مى شود كه در ستون وضع سواد و تحصيل اظهار كرده اند كه با سواد هستند. در مقاله حاضر متغير سطح تحصيلات به گونه ایى از داده هاى موجود استخراج و ساخته

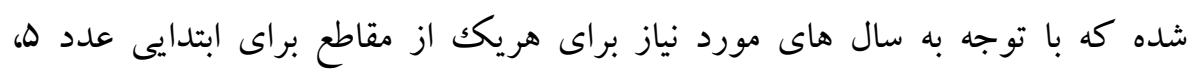

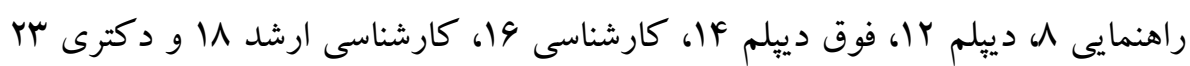
در نظر كرفته شده است.

تجربه كارى بالقوه(exp): به دليل آنكه اطلاعات دقيقى از ميزان تجربه كارى افراد

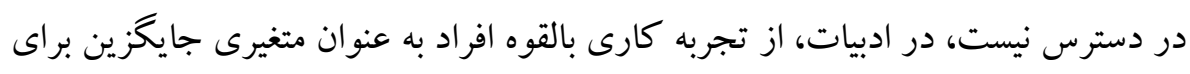


متغير تجربه، استفاده مى شود. فرضى كه براى ساختن اين متغير وجود دارد اين است كه

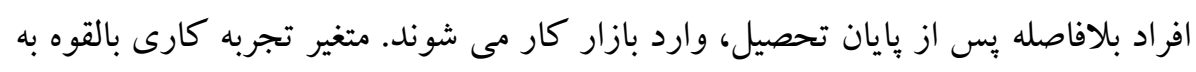
صورت متغير زير تعريف مى شود:

Expi $=$ agei - schoolingi -6

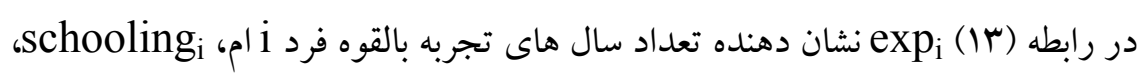

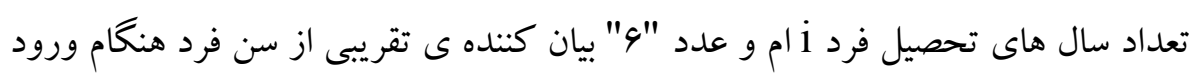
به دوره ابتدايى است.

اثر تجربه بر دستمزد بصورت يكك تابع درجه دوم تصريح مى شود. در واقع افزايش

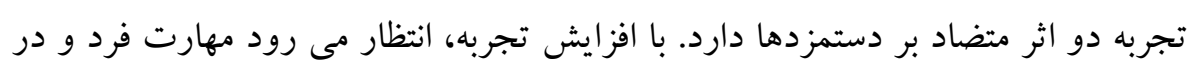

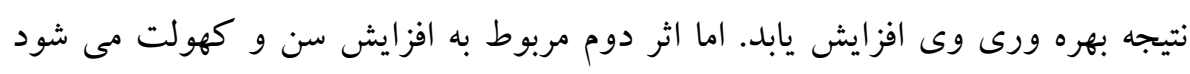

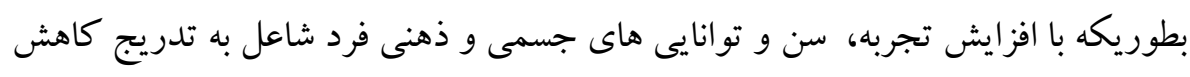

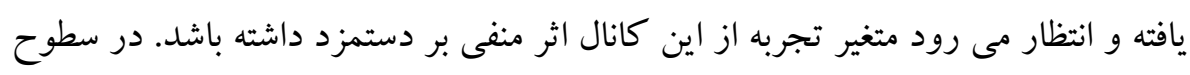

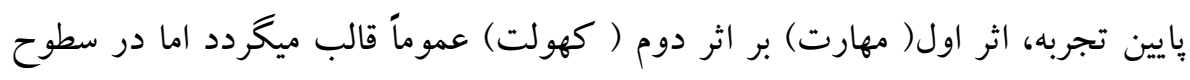

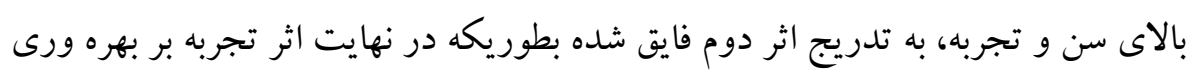

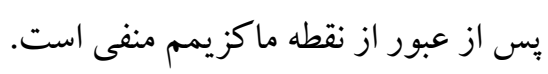

\section{وضعيت زناشويي(married): در برسش نامه هزينه و درآمد خانوار، در قسمت}

خصوصيات اجتماعى اعضاى خانوار، ستونى با عنوان وضع زناشويى وجود دارد كه در

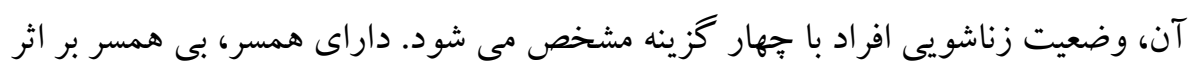

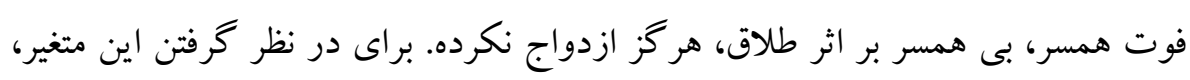

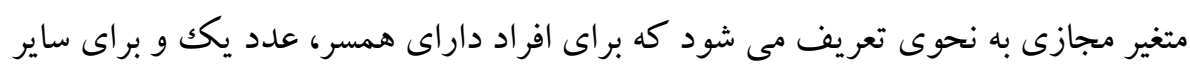
مو ارد عدد صفر نشان داده شود. 
جنسيت(gender): متغير جنسيت نيز از دو بخش زنان و مردان تشكيل شده كه در

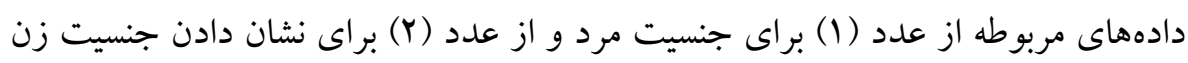

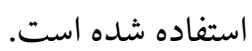

درآمل ماهيانه ناشى از كار(E): منظور از در آمد ماهيانه اين است كه يك فرد در

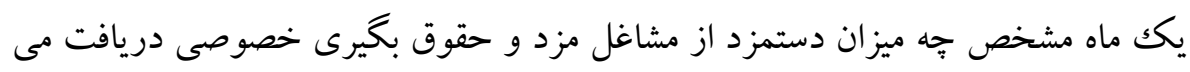

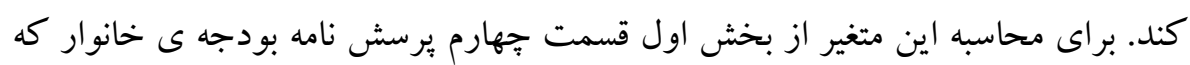
درآمدهاى بولى اعضاى شاغل خانوار از مشاغل مزد و حقوق بخيرى را شامل مى گرددد،

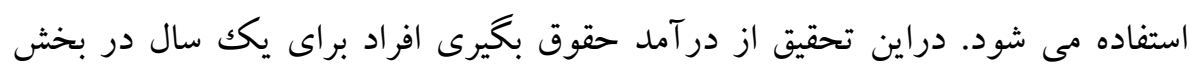
خصوصى به عنوان متغير دريافتى ها استفاده شده است.

تفاوت ميانگين و انحراف معيار در آمد افراد به تفكيك تحصيلات در سطوح دييلم، كارشناسى، كارشناسى ارشد و دكترى در جدول ( (1) ارايه شده است. همانطور كه مشاهده مى شود با افزايش سطح تحصيلات ميانگين و همجنين نوسانات دريافتىها افزايش بيدا

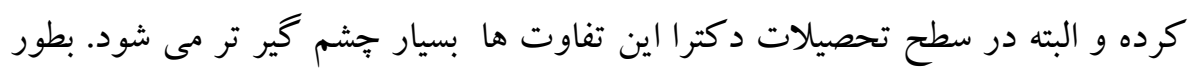

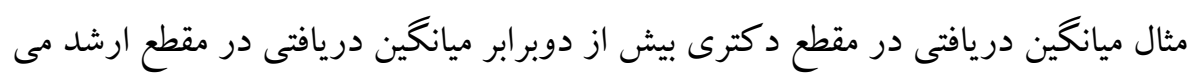

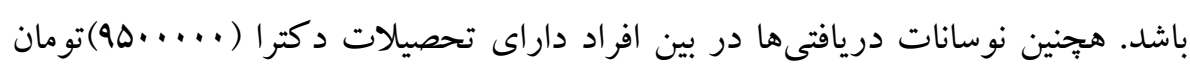

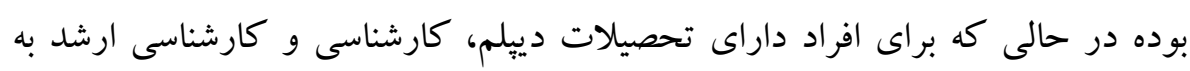

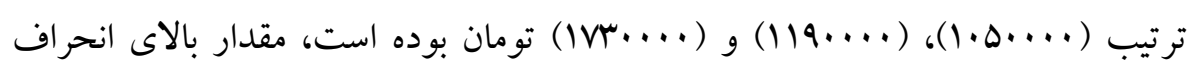
معيار در مقطع دكترا مىتواند به اين علت باشد كه بسيارى از مشاغل و بستهاى مديريتى

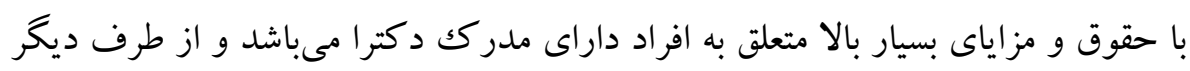
بسيارى از اين افراد به دليل كيفيت بايين تحصيلات يا مشاغل نامربوط، دريافتىهاى بـ بسيار

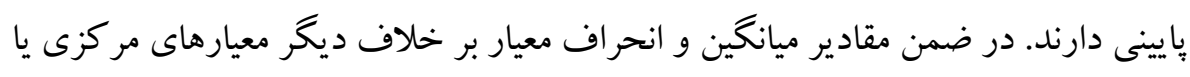

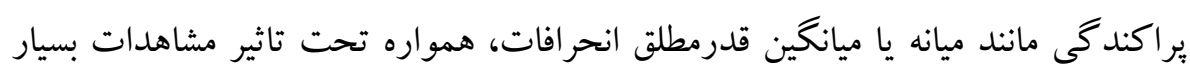

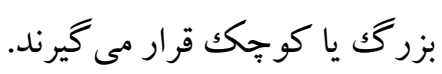


\ IVY

جدول ا: ميانكين و نوسانات دريافتى ماهانه در سطحهاى مختلف تحصيلات (سال 9011)

\begin{tabular}{|c|c|c|}
\hline نوسانات دريافتىها(انحر اف معيار) & ميانگين دريافتىها & سطح تحصيلات \\
\hline $1 \cdot \Delta \ldots$ & $11 r \ldots$ & دييلم \\
\hline $119 \ldots$ & $194 \ldots$ & كارشناسى \\
\hline IVr.... & $r \cdot \wedge \cdot \ldots$ & كارشناسى ارشد \\
\hline $90 \ldots .$. & F^s.... & دكترا \\
\hline
\end{tabular}

توضيحات: واحد اندازه گيرى مقادير ميانخين و انحر اف معيار دريافتى ها به تومان مىباشد.

ع-r. نتايج تخمين

در جدول (Y) نتايج تخمين معادله دريافتى سرمايه انسانى مينسر بر اساس مدل

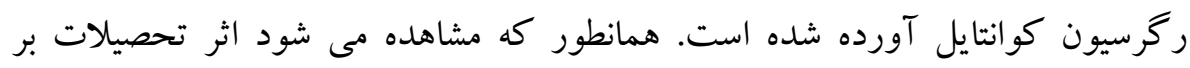
دريافتى شاغلين ( بازده تحصيلات) در همه دهك هاى دريافتى مثبت است. به علاوه اين

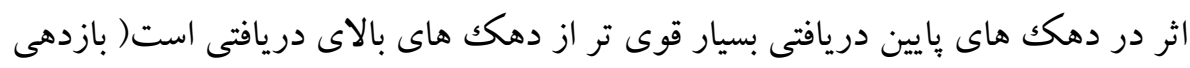

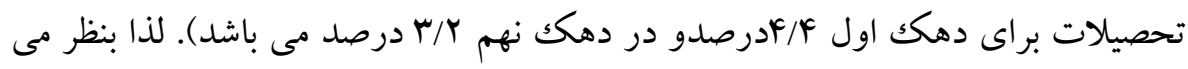

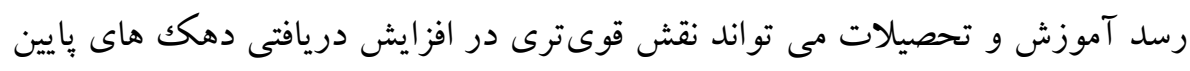

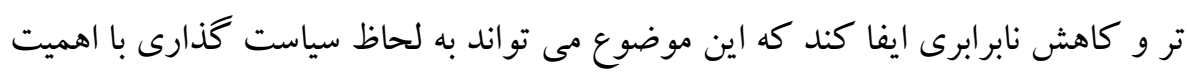
تلقى شود. همجنين براى متغير توضيحى جنسيت مشاهده مى شود كه جنسيت زن در همده دهك ها اثر منفى بر دريافتىها داشته و شدت اين اثر در دهك هاى بايين دريافتى( درصد در دهك اول) بسيار بيشتر از دهك هاى بالاى دريافتى (^- درصد در دهك

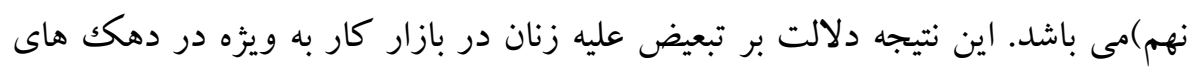

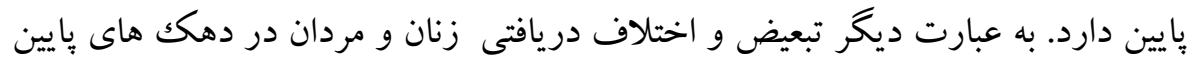

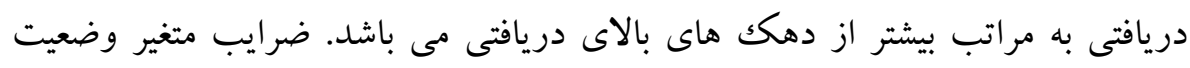
زناشويى نيز نشان مى دهد كه تاهل همواره تاثير مثبت بر دريافتى افراد داشته و مقدار اين تاثير در دهك هاى بايين دريافتى بيشتر از دهك هاى بالا مى باشد.

براى بررسى اثر تجربه بر دريافتى شاغلين، توان دوم متغير تجربه نيز در الكو لحاظ

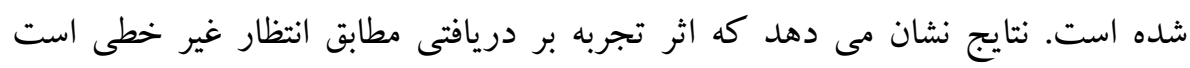


بطوريكه ضريب (توان اول) تجربه مثبت و توان دوم آن منفى مى باشد. لذا هر جند با

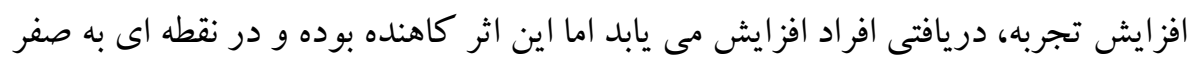

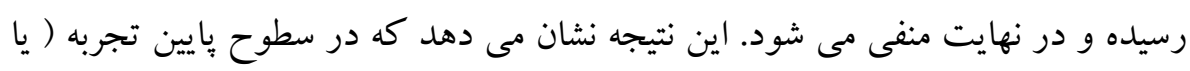

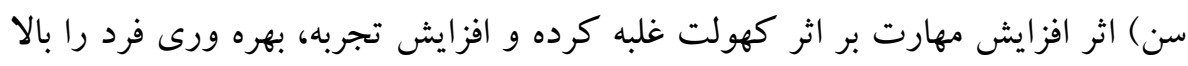

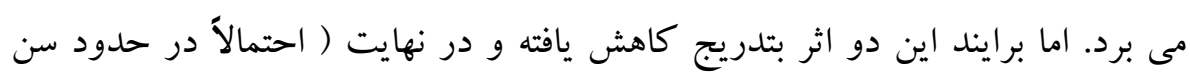

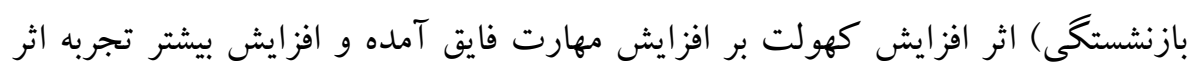

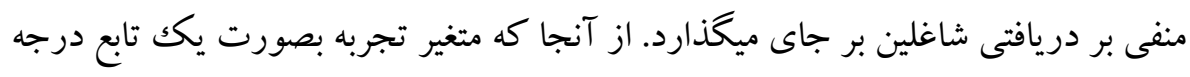

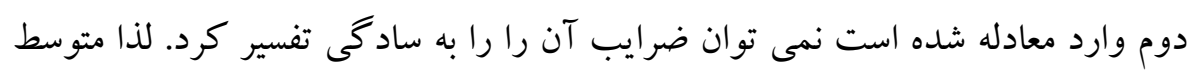

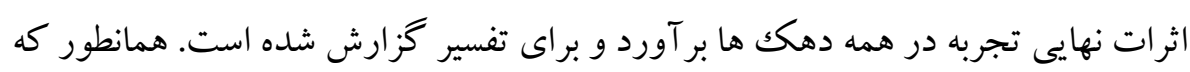

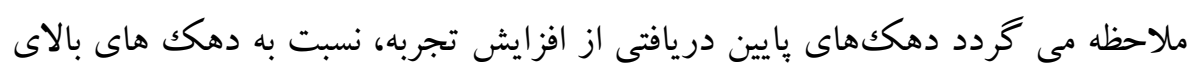
دريافتى بيشتر منتفع شدهاند.

\begin{tabular}{|c|c|c|c|c|c|c|c|c|c|}
\hline دهك & هشتم & هفتم & ششم & دهن & جهارم & سوم & دوم & دهك & \\
\hline $\begin{array}{l}\cdot / \cdot r \text { TS } \\
(\cdot / \cdot \cdot)\end{array}$ & $\begin{array}{l}. / \cdot \pi \\
(\cdot / \cdots)\end{array}$ & $\begin{array}{l}\cdot / \cdot \mu k \cdot \\
(\cdot / \cdot \cdot)\end{array}$ & $\begin{array}{l}\cdot / \cdot r F \Delta \\
(\cdot / \cdot \cdot)\end{array}$ & $\begin{array}{l}\cdot / \cdot r \Delta q \\
(\cdot / \cdot \cdot)\end{array}$ & $\begin{array}{l}\cdot / \cdot r v q \\
(\cdot / \cdot \cdot)\end{array}$ & $\begin{array}{l}\cdot / \cdot q \cdot v \\
(\cdot / \cdot \cdot)\end{array}$ & $\begin{array}{l}\cdot / \cdot \text { Frg } \\
(\cdot / \cdots)\end{array}$ & $\begin{array}{l}\cdot / \cdot F q \mid \\
(\cdot / \cdots)\end{array}$ & تحصيلات \\
\hline $\begin{array}{l}\cdot / \cdot \mid f F \\
(\cdot / \cdot \cdot)\end{array}$ & $\begin{array}{l}. / \cdot 19 V \\
(\cdot / \cdots)\end{array}$ & $\begin{array}{l}\cdot / \cdot 1 \mathrm{VV} \\
(\cdot / \cdots)\end{array}$ & $\begin{array}{l}\cdot / \cdot 1 \wedge 9 \\
(\cdot / \cdots)\end{array}$ & $\begin{array}{l}\cdot / \cdot r \cdot F \\
(\cdot / \cdot \cdot r)\end{array}$ & $\begin{array}{l}\cdot / \cdot r \mu \\
(\cdot / \cdot \cdot)\end{array}$ & $\begin{array}{l}\cdot / \cdot r \Delta V \\
(\cdot / \cdot \cdot)\end{array}$ & $\begin{array}{l}\cdot / \cdot r q 1 \\
(\cdot / \cdot \cdot)\end{array}$ & $\begin{array}{l}\cdot / \cdot r 9 \Delta \\
(\cdot / \cdot \cdot)\end{array}$ & تجربه \\
\hline $\begin{array}{c}-\cdot / \cdots) \wedge \\
(\cdot / \cdots)\end{array}$ & $\begin{array}{c}-\cdot / \cdots r r \\
(\cdot / \cdots)\end{array}$ & $\begin{array}{c}-\cdot / \ldots r f \\
(\cdot / \cdots)\end{array}$ & $\begin{array}{c}-\cdot / \cdots r V \\
(\cdot / \cdots)\end{array}$ & $\begin{array}{l}-\cdot / \cdots r \\
(\cdot / \cdots)\end{array}$ & $\begin{array}{c}-\cdot / \cdots r f \\
(\cdot / \cdots)\end{array}$ & $\begin{array}{l}-\cdot / \cdots r \\
(\cdot / \cdots)\end{array}$ & $\begin{array}{c}-\cdot / \cdots+v V \\
(\cdot / \cdots)\end{array}$ & $\begin{array}{c}-. / \cdots 90 \\
(\cdot / \cdots)\end{array}$ & توان دوم \\
\hline $\begin{array}{l}-\cdot / \cdot \wedge \Delta \wedge \\
(\cdot / \cdots)\end{array}$ & $\begin{array}{l}-\cdot / \cdot v 91 \\
(\cdot / \cdots)\end{array}$ & $\begin{array}{l}-\cdot / \cdot \wedge \Delta \Delta \Delta \\
(\cdot / \cdots)\end{array}$ & $\begin{array}{l}-. / .9 r \Delta \\
(\cdot / \cdots)\end{array}$ & $\begin{array}{l}-. / .9 k 4 \\
(\cdot / \cdots)\end{array}$ & $\begin{array}{c}-\cdot / \mathrm{rur} \\
(\cdot / \mathrm{m})\end{array}$ & $\begin{array}{l}-\cdot \cdot / \mathrm{A} \mid r \\
(\cdot / \cdots)\end{array}$ & $\begin{array}{l}-\cdot / Y F Y . \\
(\cdot / \cdots)\end{array}$ & $\begin{array}{l}-\cdot / \text { TVVA } \\
(\cdot / \cdots)\end{array}$ & جنسيت \\
\hline $\begin{array}{l}\cdot / \cdot \Delta 10 \\
(\cdot / \cdots))\end{array}$ & $\begin{array}{l}\cdot / \cdot \Delta F \\
(\cdot / \cdots)\end{array}$ & $\begin{array}{l}. / .91 \\
(\cdot / \cdots)\end{array}$ & $\begin{array}{l}\cdot / \cdot v \mid f \\
(\cdot / \cdots)\end{array}$ & $\begin{array}{l}\cdot / \cdot \wedge r) \\
(\cdot / \cdots)\end{array}$ & $\begin{array}{l}\cdot / \cdot 199 \\
(\cdot / \cdots)\end{array}$ & $\begin{array}{l}\cdot / \cdot q \cdot r \\
(\cdot / \cdots)\end{array}$ & $\begin{array}{l}\cdot / \cdot 91 \\
(\cdot / \cdots)\end{array}$ & $\begin{array}{l}\cdot / 1 \cdot \wedge \Delta \\
(\cdot / \cdots)\end{array}$ & زناشويى \\
\hline $\begin{array}{l}\cdot / \cdot v V \\
(\cdot / \cdots)\end{array}$ & $\begin{array}{l}\cdot / \cdot v \Delta \\
(\cdot / \cdots)\end{array}$ & $\begin{array}{l}\cdot / \cdot \cdot \mathrm{VV} \\
(\cdot / \cdots)\end{array}$ & $\begin{array}{l}\cdot / \cdot v q \\
(\cdot / \cdots)\end{array}$ & $\begin{array}{l}\cdot / \cdot \wedge r \\
(\cdot / \cdots)\end{array}$ & $\begin{array}{l}\cdot / \cdot \wedge \wedge \\
(\cdot / \cdots)\end{array}$ & $\begin{array}{l}\cdot / \cdot 9 r \\
(\cdot / \cdots)\end{array}$ & $\begin{array}{l}\cdot / \cdot 1 \cdot 1 \\
(\cdot / \cdots)\end{array}$ & $\begin{array}{l}\cdot / \cdot 1 \mu r \\
(\cdot / \cdots)\end{array}$ & تجربه(متوسط اثرات نهايى) \\
\hline
\end{tabular}


از آنجايى كه رابطه دريافتى و تجربه بصورت فرم درجه دوم مى باشد مى توان تجربه

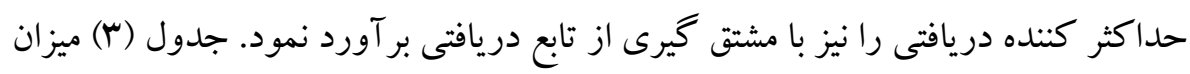
تجربه در سطح حداكثر دريافتى را براى سه دهك اول، ينجم و دهم ارايه مى دهد. همانطور كه مشاهده مى شود در دهك اول دريافتى به طور متوسط افراد در سطح تجربه

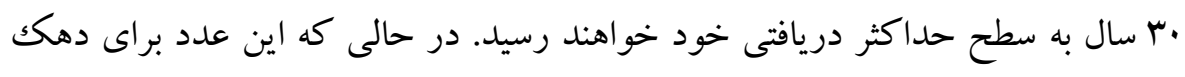

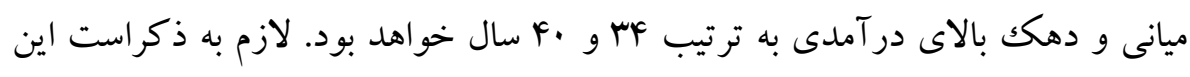
اعداد سطحى از تجربه را نشان مىدهد كه تابع دريافتى در سطوح مذكور حداكثر مى شود. به عبارت ديخر در اين سطوح از تجربه كارى، دريافتى فرد به بالاترين سطح خود خواهد

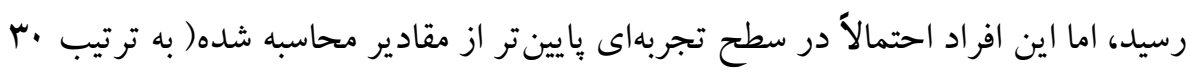

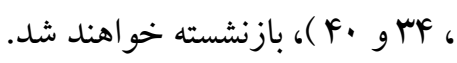

\begin{tabular}{|c|c|c|c|}
\hline دهك نهم & دهك ينجم & دهك اول & \\
\hline$f$. & $\mu_{F}$ & $\mu$. & ميز حداكثر دربه در سطح \\
\hline
\end{tabular}

\section{ع-ع. سهم تبعيض جنسيتى در تفاوت دريافتى زنان و مردان}

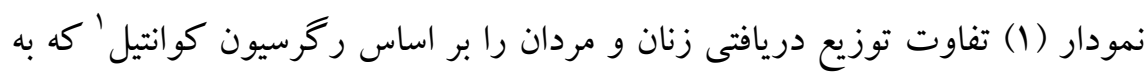

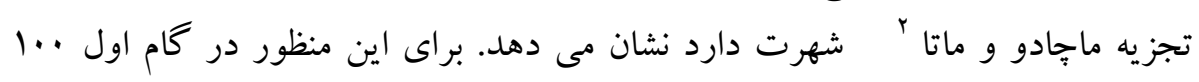

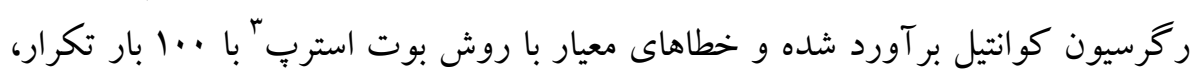

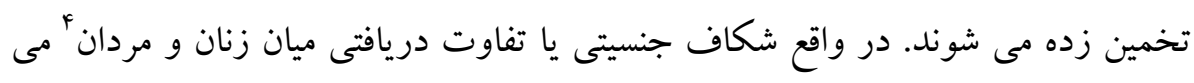

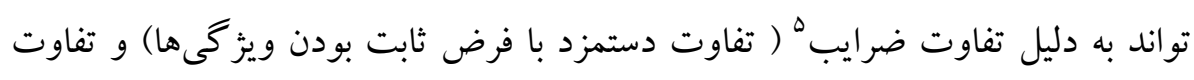

1. Quantile Regression

2. Machado and Mata Decomposition(2005)

3. Bootstrapping

4. Total Differential

5. Effects of Coefficients

6. Effects of Characteristics 
ويز گى هاى آنها' ( مانند تحصيلات) باشد. اثر اول را مى توان تبعيض در بازار كار عليه

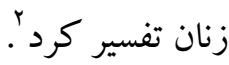

مطابق نتايج حاصله، شكاف جنسيتى يا تفاوت دريافتى زنان و مردان در كوانتيل بايين

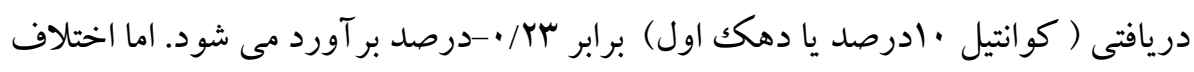

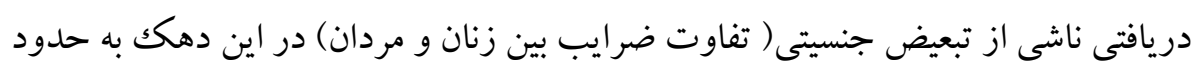

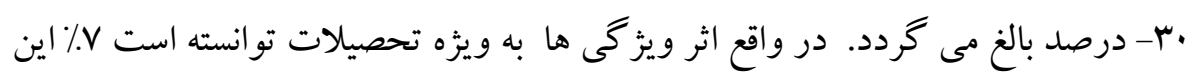

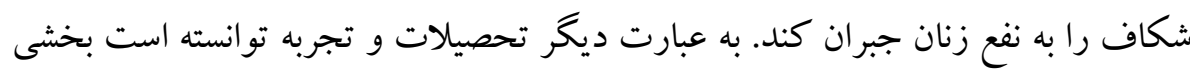

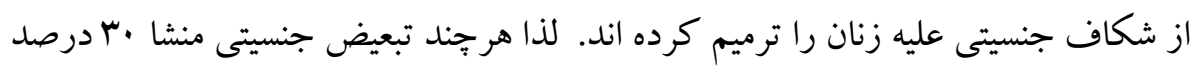

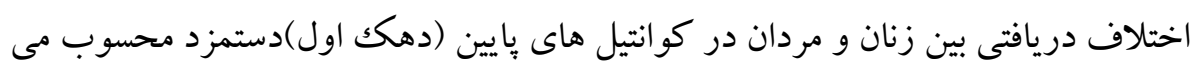
شود اما لادرصد از اين شكاف به دليل تفاوت هاى جنسيتى در توزيع تحصيلات و تجربه

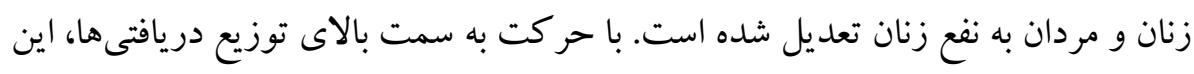

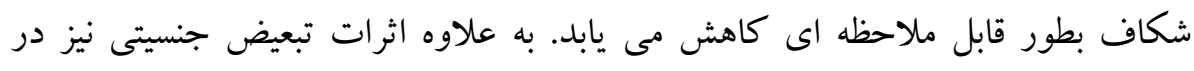

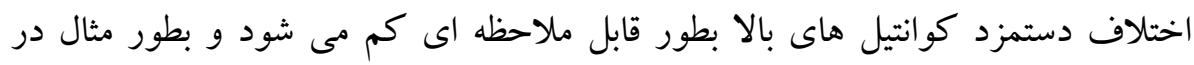

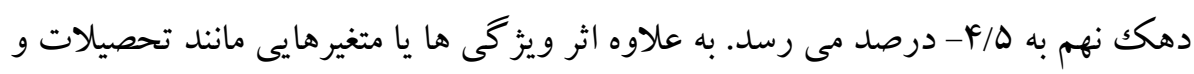
تجربه در اختلاف دريافتى زنان و مردان در تمامى دهك ها مثبت و كم و بيش ثابت مانده اند كه نشان مىدهد تحصيلات و تجربه به نفع زنان عمل كرده و اثرات بيشترى بر دريافتى

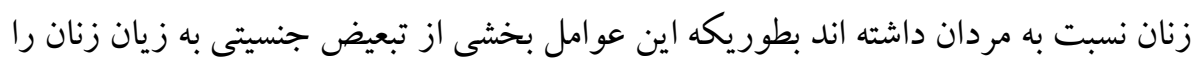

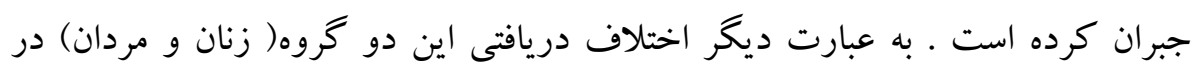


كوانتيل هاى مختلف به لحاظ اختلاف ويزگى ها (مانند تحصيلات و تجربه) به نفع زنان مثبت بوده است كه نشان مى دهد بازار كار باداش بيشترى به تحصيلات و تجربه زنان داده است هر جِند اين بِاداش قابل ملاحظه نيست.

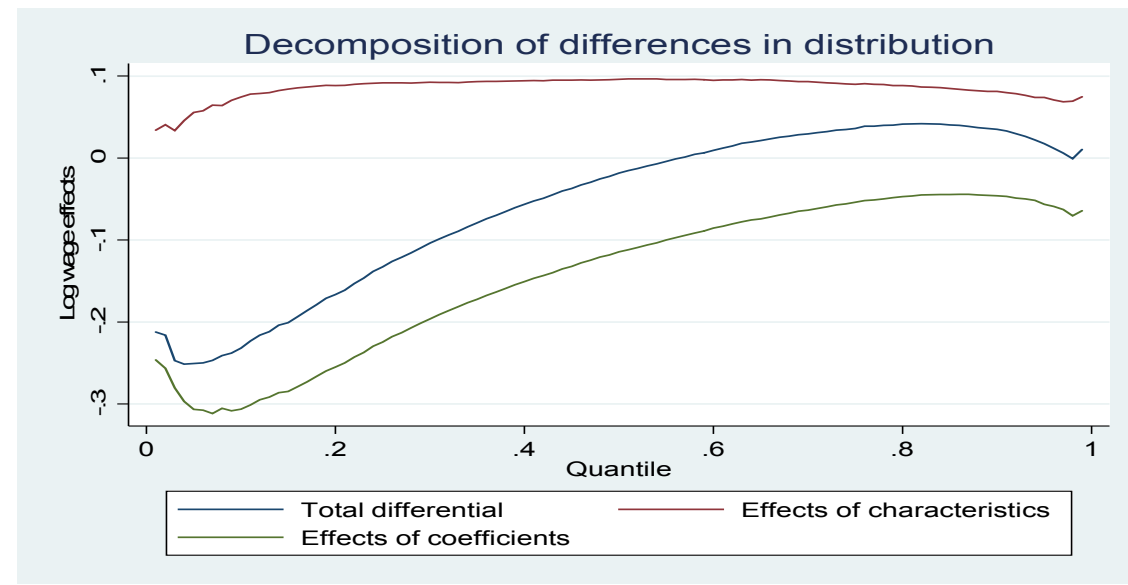

نمودار ا: نمودار تفكيك اثر جنسيت

0. خلاصه و نتيجه كيرى

در اين إثوهش به منظور بررسى اثر تحصيلات بر دريافتى شاغلين و محاسبه نرخ

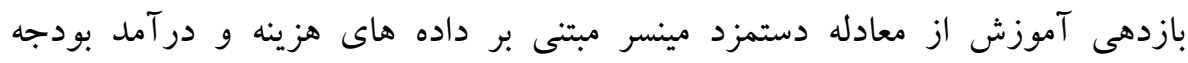

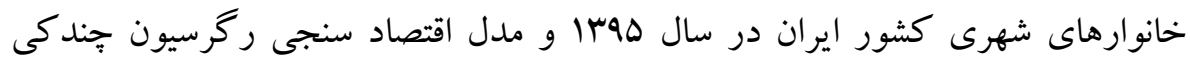

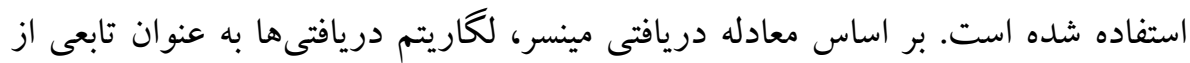
تحصيلات و ساير متغير هاى كنترل مانند تجربه و جنسيت تصريح شده و ضريب

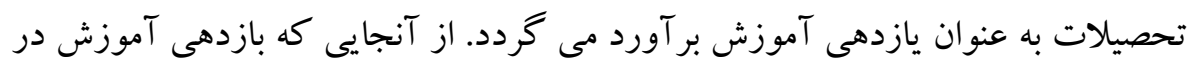

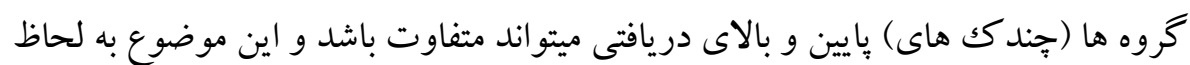

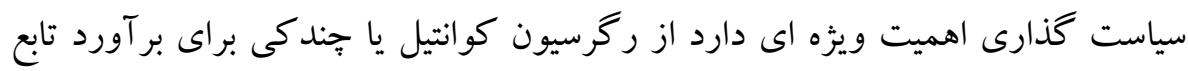

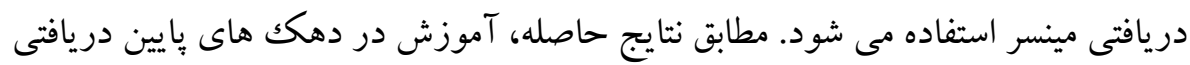

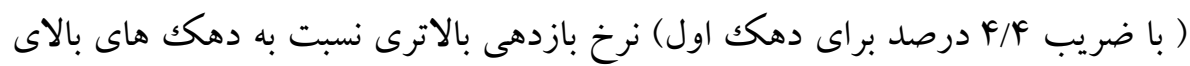


دريافتى ( با ضريب س/r درصد براى دهك نهم) دارد. به عبارت ديخر تحصيلات در گروه هاى بايين دريافتى اثر مثبت قوى ترى داشته است. اين موضوع مى تواند براى سياست

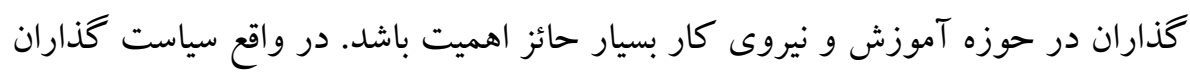

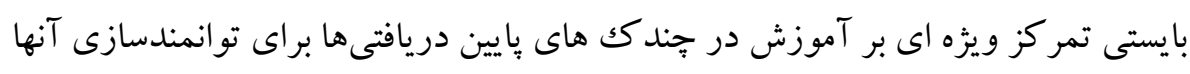

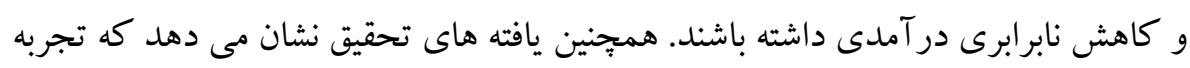

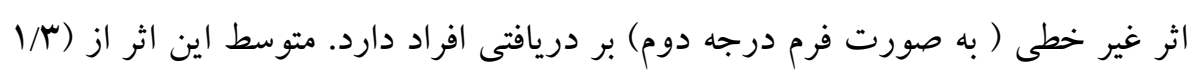

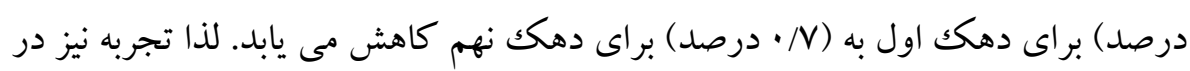

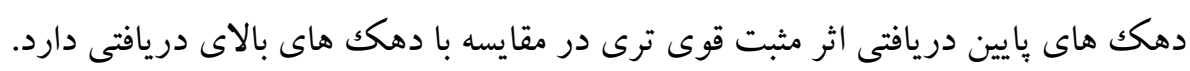

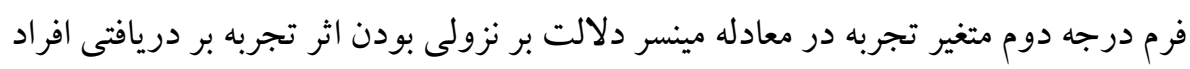

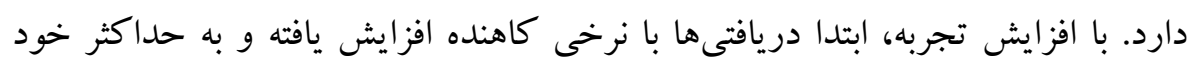

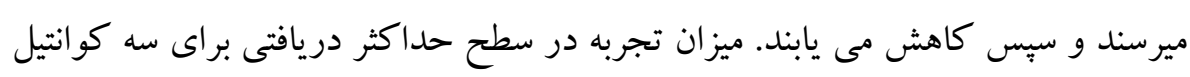

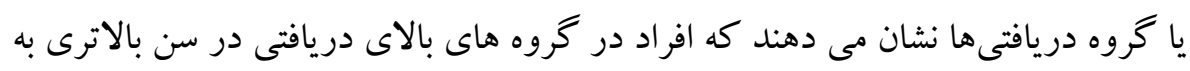

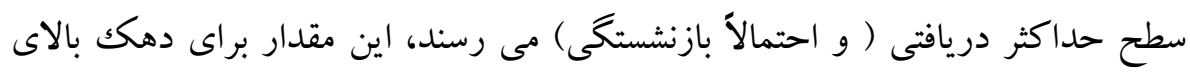

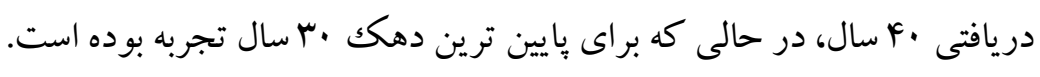

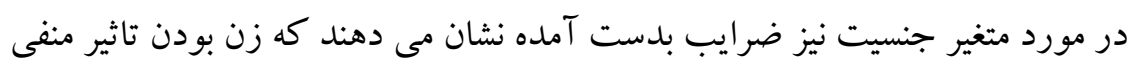

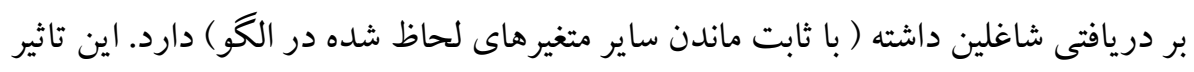

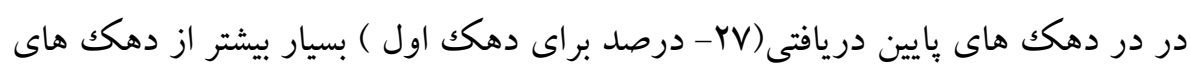
بالاى دريافتى (N/ه - درصد براى دهك نهم) است. در واقع تبعيض جنسيتى در بازار كار

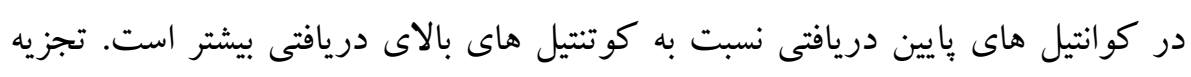

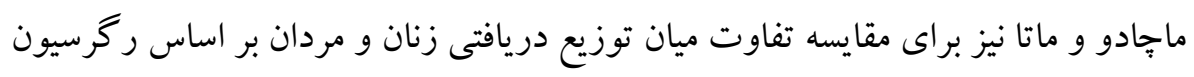

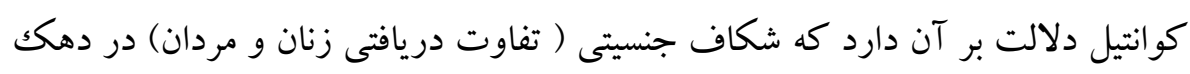

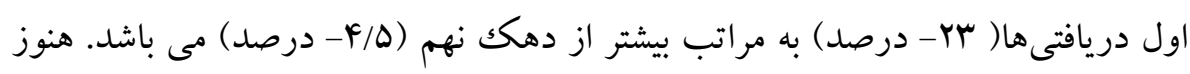

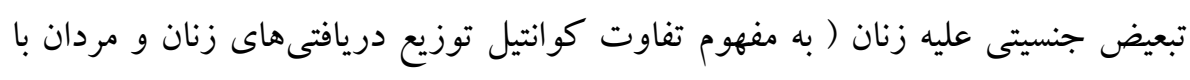

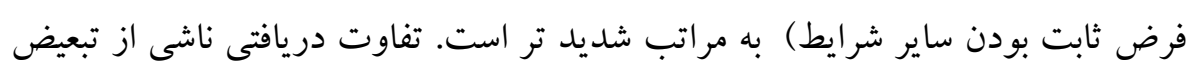


جنسيتى براى دهك اول .ب- درصد و براى دهك نهم ه/ه- درصد بر آورد مى شود. لذا

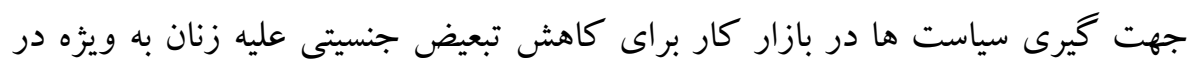
دهك هاى بايين ضروررى است. براى متغير وضعيت زناشويى نيز نتايج بيانكر اين موضوع هستند كه تاهل همواره تاثير

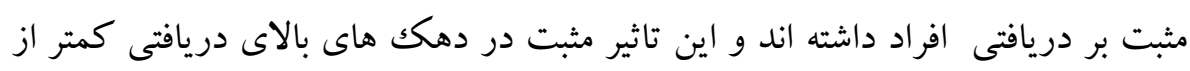
دهك هاى بايين دريافتى است.

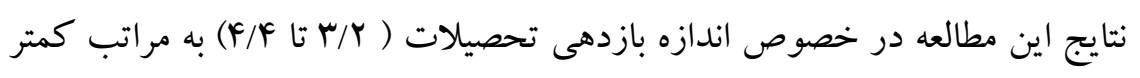

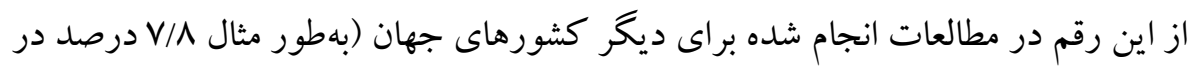

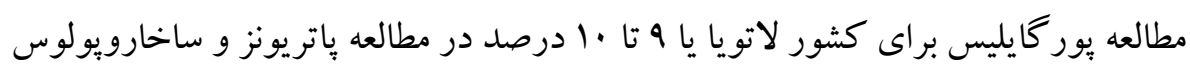

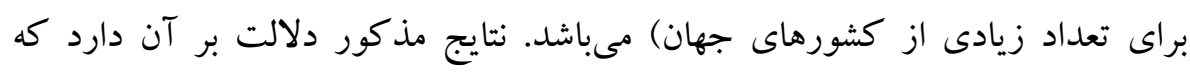

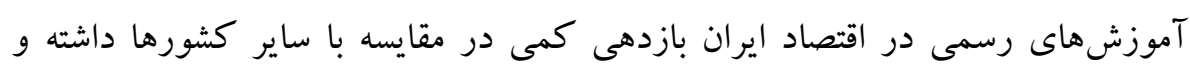

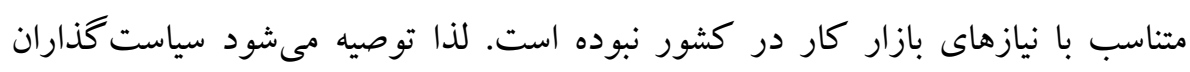

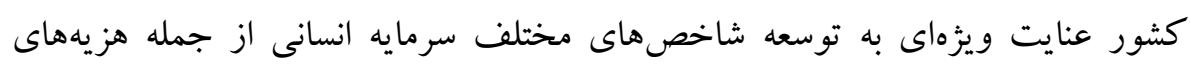

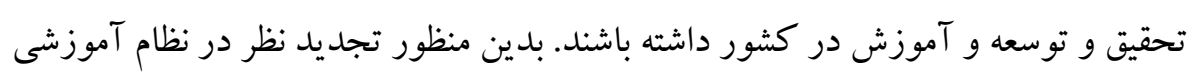

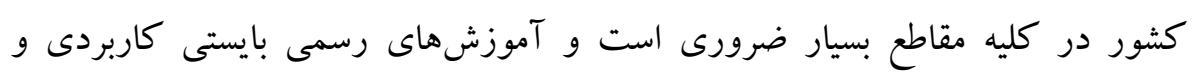

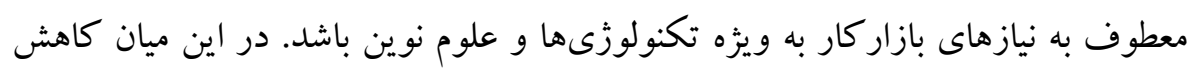

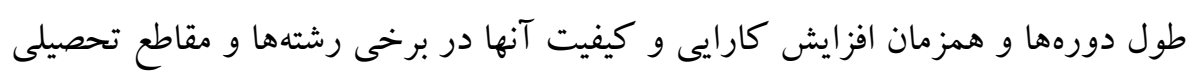
نيز مى تواند مورد توجه قرار كيرد. 
- Afshari, Z. (1998). The effect of higher education on earnings in Iran employees by using the Mincer model. Journal of research and planning on higher education, 17, 59-78. (In Persian)

- Bhatti, S. (2013). Estimation of the Mincerian wage model and different econometrics issues. PHD dissertation. University de Bourgogne.

- Chiswick, B. R. (2003). Jacob Mincer, experience and the distribution of earning. IZA Discussion paper. No. 87.

- Depcken, C., Chiseni, C. \& Ita, E. (2019). Returns to Education in South Africa: Evidence from the National Income Dynamics Study. Zagreb International Review of Economics \& Business, 22(1), 1-12.

- Dezhpasand, F., Arabmazar, A. \& Seyfi, Shapur. (2016). Study the impact of education and experience on earning. Journal of economics and modeling. 7(25), 75-101. (In Persian)

- Eide, E. R. \& Showalter, M. H. (2010). Human capital, in economics of education, Edited by: Dominic J. Brewer and Patrick J. McEwan, Oxford, Academic Press, 27-32.

- Emadzadeh, M., Samadpur, N., Ranjbar, H. \& Firuzeh, A. (2014). The Effect of Education on health in Iran: A Production Function Approach. Journal of economic modeling research, 4(15), 147-178. (In Persian)

- Falahati, A., Fattahi, S. \& Goli, S. (2017). Demand for education and estimating the share of education in income inequality. Journal of quantity economics, 11(37), 23-44. (In Persian)

- Gunawan, E. (2012) International Journal of Social Sciences and Humanity Studies, 4(1), 1309-8063 (Online)

- Harmon, C., Hogan, V. \& Walker, I. (2002). "Dispersion in the economic return to schooling". Labor economics, 10(2), 205-214.

- Jannati Moshkani, A., Sameti, m., Khosh akhlagh, R., Esfahani, R. \& Emadzadeh, M. (2011). The Impact of Education Costs on Human Capital and Economic Growth Using Computable General Equilibrium Model. Journal of economic modeling research, 2(5), 103-130. (In Persian)

- Keshavarz, G. \& Javaheri, M. (2017). overeducation and Wages in the Labor Market: Evidence from Iranian microeconomics Data. Journal of economic research, 52(2), 345-368. (In Persian)

- Mahdavi, A. \& Piruzrahi, Z. (2018). Assessment of private return rate of postgraduate education in Iran using multilevel models. Journal of research and planning on higher education, 4, 145-162. (In Persian)

- Mincer, J. (1960). "Investment in human capital and personal income distribution". Journal of political economy, 66, 281-302. 
- Mincer, J. (1974). "Schooling, experience and earning". Columbia UN. Press, New York.

- Mook, P., Patrinos, H. \& Venkataraman, M. (1999). Education and Earnings in a transition economy the case of Vietnam. Economics of education review, 22(5), 503-510.

- Naderi, A., Rameshi, R. \& Nami, K. (2013). Rates of Education Efficiency in Iran by Gender of Employed Graduates and Type of Education. Journal of educational planning studies, 5, 30-42. (In Persian)

- Psacharopoulos, G. \& Patrinos, H. (2018). Returns to Investment in Education: A Decennial Review of the Global Literature. World Bank, policy research working papers, 2018-04.

- Psacharopoulos, G. \& Patrinos, H. A. (2004). Returns to investment in education: A further update. Education economics, 12(2), 111-134.

- Romele, L. \& Purgailis, M. (2013). Estimation of private and social rates of return to investments in education in Lativa. European Integration studies, 7, 51-59.

- Romele, L. \& Purgailis, M. (2013). Estimation of private and social rates of return to investments in education in Latvia. European Integration Studies, 7, 51-59.

- Rossi, A. \& Hersch, J. (2008). Double your major, double your return?. Journal of economics of education review, 27, 375-386.

- Schultz, T. (1960), Capital formation by education. Journal of political Economy, 68(6), 571-583.

- Stevens, H., Kurlaender, M. \& Grosz, M. (2019). Career Technical Education and Labor Market Outcomes Evidence from California Community College, 54(4), 986-1026 


\title{
The Effect of Education on Labor Wages in Iranian Urban Households Based on Quantile Regression*
}

\author{
Mohsen Mehrara ${ }^{1}$, Ghasem Elahi ${ }^{2}$
}

Received: 2019/10/12

Accepted: 2020/03/08

\begin{abstract}
The purpose of this article is to examine the impact of education and work experience on earning. For this purpose, Mincer's wage equation, quantile regression estimation method and the microdata from Iranian survey of household income and expenses in 2016 have been used. Estimation results show that education returns are positive in all income quantiles, and education in lower-income quantiles has a stronger positive effect than in higher-income quantiles. Also, the average experience have a positive effect on the earnings of individuals, with a stronger effects in low-income quantiles than high-income quantiles. Gender coefficients show that female earnings in all income quantiles are much lower than males, but this negative effect was much bigger in lower-income quantiles, implying gender-based discrimination against women in low-income quantiles. According to Machado and Mata's decomposition, gender discrimination (against females) was estimated, $-30 \%$ in the first decile, and $-4.5 \%$ in the ninth decile. Women's education has narrowed the gap somewhat on behalf of women. According to the results, education efficiency in Iran is far lower than many other countries in the world. Therefore, it is necessary to reform educational structures, in particular to guide them towards labor market needs and economic benefits.
\end{abstract}

Keywords: Education, Work Experience, Mincer Earning Equation, Quantile Regression.

JEL Classification: C21, I21, J24.

\footnotetext{
* This Article is from a Doctoral Thesis in Economics.

1. Prof. of Economics, University of Tehran, (Corresponding Author) Email: mmehrara@ut.ac.i

2.PhD Student of Kish International Campus, University of Tehran_Email: ghasem.elahi@ut.ac.ir
} 